\title{
Effects of Different Concentrate Feed Proportions on Ruminal Ph Parameters, Duodenal Nutrient Flows and Efficiency of Microbial Crude Protein Synthesis in Dairy Cows During Early Lactation
}

\author{
Katharina Bünemann ${ }^{1}$, Maren Johannes ${ }^{1}$, Rolf Schmitz ${ }^{1}$, Julia Hartwiger ${ }^{1}{ }^{(1)}$, \\ Dirk von Soosten ${ }^{1, *} \mathbb{C}$, Liane Hüther ${ }^{1}$, Ulrich Meyer ${ }^{1}$, Heiner Westendarp ${ }^{2}$, Jürgen Hummel ${ }^{3}$, \\ Annette Zeyner ${ }^{4}$ (D) and Sven Dänicke ${ }^{1}$ \\ 1 Institute of Animal Nutrition, Friedrich-Loeffler-Institut (FLI), Federal Research Institute for Animal Health, \\ 38116 Braunschweig, Germany; Katharina.Buenemann@fli.de (K.B.); maren.johannes@gmail.com (M.J.); \\ rolf_schmitz@gmx.net (R.S.); juliahartwiger@gmx.de (J.H.); Liane.Huether@fli.de (L.H.); \\ Ulrich.Meyer@fli.de (U.M.); Sven.Daenicke@fli.de (S.D.) \\ 2 Faculty of Agricultural Sciences and Landscape Architecture, University of Applied Sciences, \\ 49076 Osnabrück, Germany; h.westendarp@hs-osnabrueck.de \\ 3 Department of Animal Sciences, University of Göttingen, 37077 Göttingen, Germany; jhummel@gwdg.de \\ 4 Institute of Agricultural and Nutritional Sciences, Martin-Luther-University Halle-Wittenberg, \\ 06120 Halle (Saale), Germany; annette.zeyner@landw.uni-halle.de \\ * Correspondence: Dirk.von_Soosten@fli.de; Tel.: +49-531-58044-136
}

Received: 20 January 2020; Accepted: 7 February 2020; Published: 8 February 2020

check for updates

Simple Summary: Around calving, cows exhibit a depression in feed intake. An imbalance between energy intake and energy demands occurs, which results in a negative energy balance. Concentrate feed proportions of the ration are increased to compensate that energy deficit. The accompanying increase in concentrate intake leads to higher production of short chain fatty acids, which in turn might lower the ruminal $\mathrm{pH}$. A ruminal $\mathrm{pH}<5.8$ for a certain period of time can lead to subacute ruminal acidosis. Keeping the ruminal $\mathrm{pH}$ within the physiological range is important for microorganisms colonizing the rumen. Those microorganisms metabolize feed protein via ammonia or amino acids to microbial protein, which is then available for the host. Microbial efficiency is limited by availability and balance of nitrogen and energy, the latter is mostly provided as starch. The aim of the present study was to examine influences of different concentrate feed proportions and of microbial efficiencies on ruminal $\mathrm{pH}$ parameters, nutrient flows and digestibilities. Therefore, cows were additionally grouped according to their individual microbial efficiency. The concentrate treatment effect did not cause differences in the mentioned parameters. However, more microbial efficiency cows exhibited higher nutrient flows but lower digestibilities.

Abstract: The aim of the study was to examine different $\mathrm{pH}$ parameters, such as variations throughout the day, depending on differing concentrate feed proportions. Moreover, special attention was payed to individual variation in microbial efficiencies (microbial crude protein/fermented organic matter) and their relation to ruminal $\mathrm{pH}$, nutrient flows and digestibilities. For this, cows were grouped according to microbial efficiency (more, $\mathrm{n}=5$, vs. less efficient cows, $\mathrm{n}=4$ ). After calving, thirteen ruminally cannulated pluriparous cows, including nine duodenally cannulated animals, were divided into groups offered rations with a lower ( $35 \%$ on dry matter basis, $n=7$ ) or a higher $(60 \%$ on dry matter basis, $\mathrm{n}=6)$ concentrate feed proportion. Ruminal $\mathrm{pH}$ parameters were assessed continuously by using intraruminal probes. Nutrient flows, nutrient digestibility and microbial efficiency were determined for duodenally cannulated cows. For most ruminal $\mathrm{pH}$ parameters it seemed that individual variability was higher than the treatment effect. However, a positive relationship between actual concentrate intake and diurnal $\mathrm{pH}$ fluctuations was found. Besides, 
the effect of individually different microbial efficiencies was assessed. Again, there were no group differences for $\mathrm{pH}$ parameters. However, nutrient flows were significantly higher in more efficient cows, whereas digestibilities were lower in in more efficient cows.

Keywords: dairy cows; concentrate feed proportion; ruminal pH; nutrient flows; microbial efficiency; postpartal period

\section{Introduction}

Cows display a depression in feed intake during the transition period, which leads to an imbalance between energy intake and energy demands [1,2]. To balance this discrepancy, concentrate feed proportions of the rations (C) are often elevated post partum (p.p.). The increase of concentrate intake is accompanied by an increased production of short chain fatty acids (SCFA) in the rumen, which can affect the ruminal $\mathrm{pH}$ negatively [3,4]. To keep the ruminal $\mathrm{pH}$ within the physiological range, the absorption of SCFA through the ruminal epithelium has to increase simultaneously $[5,6]$. Another factor to compensate the elevated SCFA concentration is an increased chewing activity, which in turn increases saliva production and buffer secretion. Disappearance of SCFA is also determined by passage rate to the lower digestive tract [7]. If the imbalance between production and elimination of SCFA impacts the ruminal $\mathrm{pH}$ in a way that it drops below an appropriate threshold for a certain period of time, this can result in subacute ruminal acidosis (SARA) [7-9]. The risk of developing SARA is particularly high during the transition period, with a shift from a dry period to an early lactation diet [10]. Detection of SARA is difficult. Nevertheless, for the attempt of definition, thresholds according to Zebeli et al. [9] are used most frequently. These are described as a daily mean $\mathrm{pH}<6.16$ and the time per day with $\mathrm{pH}<5.8$ for more than 5.24 hours. However, several studies assume high individual variability in ruminal $\mathrm{pH}$ and in susceptibility to develop SARA [1,11,12].

A low ruminal $\mathrm{pH}$ can also reduce fiber digestion and therefore lower microbial efficiency, which is defined as synthesized microbial protein per fermented organic matter (mCP/fOM) [13-15]. A decrease of fiber digestion can impede an even energy provision throughout the day, which is necessary for an optimal microbial growth. The release of energy from non-structural carbohydrates is faster than the energy consumption of the microorganisms and can result in an uncoupled fermentation. This again can lead to energy spilling $[16,17]$. Energy is used for the so-called non-growth processes, such as maintaining the intracellular $\mathrm{pH}$ on an optimal level instead of using it for cell growth under low $\mathrm{pH}$ conditions $[16,18]$. However, most studies assumed stable ruminal $\mathrm{pH}$ conditions while variations throughout the day received little attention [19]. Microbial efficiency depends on availability and balance of nitrogen $(\mathrm{N})$ and fermentable energy $[15,18,20]$. Fermentability of the diet might in turn influence not only the ruminal $\mathrm{pH}$, but also the passage rate [18]. The fermentability of the diet is primarily influenced by fermentability of the contained starch. Starch fermentation is accompanied with an increase of SCFA concentration, which lowers ruminal $\mathrm{pH}$. In addition, a high amount of starch can increase passage rate, due to a smaller particle size of feedstuffs with higher starch contents compared to forage $[5,18,21]$. Yet, few studies have been conducted on the relationship between ruminal $\mathrm{pH}$, nutrient flows and microbial efficiency. Firkins et al. [22] demonstrated an improvement of $39 \%$ in microbial efficiency, due to a $15 \%$ decrease of organic matter digestibility. Therefore, they considered the increasing passage rate to be a general explanation. They proposed that substrate supply increases with enhanced passage rate, which would improve cell growth, due to an increase of growth related enzymes in the microorganisms. Additionally, an increased passage rate can decrease microbial turnover in the rumen [23]. However, investigations differ in their results concerning this relation, as higher passage rates can also lead to microbial washout [24,25].

The objective of the present study was, on the one hand, to examine different ruminal $\mathrm{pH}$ parameters depending on differing concentrate feed proportions, thereby, paying special attention 
to diurnal fluctuations. Besides, the concentrate effect on microbial efficiency, nutrient flows and digestibility was assessed. On the other hand, the study intended to investigate the relation between ruminal $\mathrm{pH}$ and microbial efficiency from a new perspective for gaining further information. Therefore, the microbial efficiency was chosen as starting point, by grouping the cows according to their individual microbial efficiency (more vs. less efficient). For this, the average microbial efficiency of $156 \mathrm{~g} \mathrm{mCP} / \mathrm{kg}$ fOM according to GfE [15] was used as threshold. Moreover, the effect of microbial efficiency on nutrient flows and digestibilities was examined. For this reason, different statistical evaluations were applied in order to appraise both the effects of varying dietary energy concentration as well as those of microbial efficiency on the parameters mentioned.

\section{Materials and Methods}

The experiment was performed in compliance with the German legislation on animal protection (Animal Welfare Act) and approved by the Lower Saxony State Office for Consumer Protection and Food Safety (LAVES, Oldenburg, Germany) in consultation with an independent ethics committee (AZ 33.19-42502-04-15/1858).

\subsection{Experimental Design}

Two diet types were created in order to induce distinct differences in energy supply and presumably ruminal $\mathrm{pH}$ parameters. While the high-caloric diet was designed to contain $60 \%$ concentrate feed, the low-caloric ration was contrasted with $35 \%$ concentrate feed.

The current study was based on 13 ruminally cannulated, pluriparous German Holstein cows, including nine additionally duodenally cannulated animals. Rumen cannula enables the access to the reticulo-rumen via the dorsal sac of the rumen. The duodenal cannula was inserted in the proximal duodenum. The experiment covered the period from 3 weeks before calving until 70 days in milk (DIM) and one additional week of duodenal chyme sampling (cows were on average in the 13th week of lactation \pm 16 days). Before parturition, all cows received the same standardized total mixed ration (TMR) consisting of $80 \%$ silage ( $70 \%$ maize silage, $30 \%$ grass silage on dry matter (DM) basis) and $20 \%$ concentrate on DM basis. After calving, animals were divided into two groups and assigned to two different concentrate feed proportions. Cows received a partial mixed ration (PMR) consisting of $48 \%$ maize silage, $20 \%$ grass silage and $32 \%$ concentrate feed. Rations for the groups with lower concentrate feed proportion $\left(\mathrm{C}_{35}\right)$ were adjusted to $35 \%$ concentrate feed by using automatic feeding stations (Intensec, B.V., Marknesse, The Netherlands). For the groups with a higher amount of concentrate $\left(\mathrm{C}_{60}\right), \mathrm{C}$ was also provided by the automatic feeders and increased from $35 \%$ to $60 \%$ during the first three weeks p.p. The components and the chemical compositions of the feedstuffs are presented in Tables 1 and 2. 
Table 1. Composition of concentrates during the dry and the lactating period.

\begin{tabular}{cccc}
\hline & \multicolumn{3}{c}{ Concentrates } \\
\cline { 2 - 4 } Components, $\mathbf{g} / \mathbf{k g}$ of Fresh Matter & Dry Period & \multicolumn{2}{c}{ Lactating Period } \\
\cline { 2 - 4 } & & $\mathbf{C}_{\mathbf{3 5}}$ & $\mathbf{C}_{\mathbf{6 0}}$ \\
\cline { 2 - 4 } & 115 & & \\
Soybean meal & 150 & 400 & 200 \\
Rapeseed meal & 330 & 150 & 213 \\
Wheat & & 144 & 213 \\
Barley & 200 & 290 \\
Maize & 296 & 50 & 50 \\
Dried sugar beet pulp & 30 & 8 & \\
Urea & 24 & 13 & 12 \\
Calcium carbonate & 15 & 10 & 10 \\
Soybean oil & 40 & & \\
Vitamin-mineral premix & & 25 & 12 \\
Vitamin-mineral premix & & &
\end{tabular}

+ Mineral feed for dry cows, ingredients per kg according to the manufacturer's specification: $10 \mathrm{~g} \mathrm{Ca} ; 120 \mathrm{~g} \mathrm{Na}$; 60 g P; 60 g Mg; 6 g Zn; 4 g Mn; 1.25 g Cu; 100 mg I; 50 mg Se; 35 mg Co; 800,000 IU vitamin A; 100,000 vitamin D; $1500 \mathrm{mg}$ vitamin E. \# Mineral feed for lactating dairy cows, ingredients per kg according to the manufacturer's specifications: 140 g Ca; 120 g Na; 70 g P; 40 g Mg; 6 g Zn; 5.4 g Mn; 1 g Cu, 100 mg I; 40 mg Se; 25 mg Co; 1,000,000 IU vitamin $\mathrm{A} ; 100,000$ IU vitamin $\mathrm{D}_{3} ; 1500 \mathrm{mg}$ vitamin $\mathrm{E}$.

Table 2. Chemical components of the dry period diet, as well as of the $\mathrm{C}_{35}$ - and $\mathrm{C}_{60}$-ration during the experimental period from day 21 antepartum until day 70 postpartum.

\begin{tabular}{|c|c|c|c|}
\hline Chemical Composition & Dry Period Diet & $\mathrm{C}_{35}$-Ration & $\mathrm{C}_{60}$-Ration \\
\hline Dry matter, g/kg & 239 & 251 & 198 \\
\hline \multicolumn{4}{|l|}{ Nutrients, $\mathrm{g} / \mathrm{kg} \mathrm{DM} \S$} \\
\hline Crude ash & 63 & 96 & 59 \\
\hline Crude protein & 131 & 144 & 153 \\
\hline Ether extract & 34 & 38 & 42 \\
\hline $\mathrm{a}^{\dagger}$ Neutral detergent fiber $_{\mathrm{om}} \$$ & 327 & 353 & 294 \\
\hline Acid detergent fiber $_{\mathrm{om}} \$$ & 225 & 204 & 169 \\
\hline Starch content & 247 & 285 & 353 \\
\hline \multicolumn{4}{|l|}{ Energy $\ddagger, \mathrm{MJ} / \mathrm{kg}$ of DM } \\
\hline ME & 10.9 & 11.3 & 11.8 \\
\hline $\mathrm{NE}_{\mathrm{L}}$ & 6.6 & 6.9 & 7.3 \\
\hline
\end{tabular}

$\ddagger$ Calculation based on equations of GfE [16]. ${ }^{\S}$ Dry matter. ${ }^{\dagger}$ Assayed with a heat-stable amylase for maize silage and concentrates. ${ }^{\$}$ Expressed exclusive of residual ash. $C_{35}$ group comprised seven ruminally cannulated cows, including four duodenally cannulated animals with an average parity of $3.8( \pm 1.5)$. The $\mathrm{C}_{60}$ group contained six ruminally and five additionally duodenally cannulated animals with an average parity of $3.4( \pm 1.4)$.

\subsection{Measurements and Sample Collections}

\subsubsection{Dry Matter Intake and Milk Yield}

Dry matter intake (DMI) was recorded for both PMR and concentrate individually by computerized feeding stations (Insentec, B.V., Marknesse, The Netherlands). Milking took place at 05:30 a.m. and 03:30 p.m. and milk yield was determined by automatic milk counters throughout the 70 DIM (Lemmer Fullwood GmbH, Lohmar, Germany).

\subsubsection{Feed and Milk Samples}

Samples of the mixed ration components were taken twice a week and pooled to a collective sample every four weeks. Samples of concentrate were collected once a week and also pooled to a collective sample monthly. Milk samples were taken twice a week during morning and evening milking and stored at $4{ }^{\circ} \mathrm{C}$ until analysis. 


\subsubsection{Rumen Fluid Samples}

Rumen fluid samples were taken after morning milking at eight time points, after calving (days p.p.: $3,7,14,21,28,42,56,70$ ) as well as in the week of duodenal chyme sampling. Rumen fluid samples were collected through the rumen cannula using a manual pump. With every sample, about $200 \mathrm{~mL}$ of rumen fluid were taken. Samples were stored at $4{ }^{\circ} \mathrm{C}$ until further analysis.

\subsubsection{Rumen $\mathrm{pH}$ and Rumination Behavior Measurements}

A ruminal $\mathrm{pH}$ measuring device (Lethbridge Research Centre Ruminal pH Measurement System, Dascor, Escondido, CA, USA) was used to record the $\mathrm{pH}$ values in the ventral sac of the rumen continuously. The $\mathrm{pH}$ values were recorded every minute and measured during several consecutive 24-h periods each week ( $2 \pm 1.16$; mean $\pm \mathrm{SD})$ from week -3 to week 10 relative to calving, as well as in the week of duodenal chyme sampling. At some periods data of individual cows were missing, due to either insufficient capacity of instruments or technical problems. However, it was ensured that at least three cows of every group were recorded in every period. Before and after each measuring period the system was calibrated in buffer solutions of $\mathrm{pH} 4$ and 7 at $39^{\circ} \mathrm{C}$.

\subsubsection{Duodenal Chyme and Faeces Samples}

Each duodenally cannulated cow received a chromium oxide marker $\left(\mathrm{Cr}_{2} \mathrm{O}_{3}\right)$ for 16 consecutive days. Marker administration started when cows were 73 DIM $( \pm 16)$ on average. During the first 10 days, the marker was inserted into the rumen through the rumen cannula in two portions of $50 \mathrm{~g}$ each at 05:00 a.m. and 5:00 p.m. During the last 6 days, the marker was inserted in four portions of $25 \mathrm{~g}$ every $6 \mathrm{~h}$. The chromium oxide marker dosing schedule was performed according to Schäfers et al. [26]. During the last 5 days of the marker administration period, samples of duodenal chyme were collected in intervals of $10 \mathrm{~h}$. Samples were collected from the duodenal cannula and pooled to a collective sample for the five sampling days and stored at $-20^{\circ} \mathrm{C}$ until further analysis.

Faeces samples were taken rectally with every duodenal chyme sampling and then pooled to a collective sample.

\subsection{Analyses}

\subsubsection{Feed and Milk Analyses}

Feed samples were analyzed according to the standard methods of the Association of German Agricultural Analysis and Research Centers (VDLUFA, method numbers are given hereafter) [15]. PMR components and concentrate were analyzed for DM (3.1), crude ash (8.1), crude protein (Dumas method, 4.1.2), starch (7.2.1, polarimetric method), ether extract (5.1.1), neutral detergent fiber ( $\mathrm{aNDF}_{\mathrm{om}}$, 6.5.1) and acid detergent fiber $\left(\mathrm{ADF}_{\mathrm{om}}, 6.5 .2\right)$ (Table 2).

Milk samples of 20 morning and 20 evening samples were analyzed for fat, protein, and lactose by an infrared milk analyzer (Milkoscan FT 6000; Foss Electric, Hillerød, Denmark).

\subsubsection{Rumen Fluid Analyses}

Short chain fatty acids (SCFA) were determined according to Geissler et al. [27]. For this, rumen fluid samples were centrifuged ( $5 \times 2400 \mathrm{~g}$ ) (Beckman J2-H2, Beckman Coulter Inc., Brea, CA, USA), $10 \mathrm{~mL}$ of the fluid phase were added to $1 \mathrm{~mL}$ of $25 \%$ sulphuric acid and centrifuged again $(20 \times 2700 \mathrm{~g})$ (Eppendorf 5417 R, Eppendorf AG, Hamburg, Germany). The supernatant was filled into GC-vials. Afterwards it was separated by gas chromatography (Clarus 680 CG, Perkin Elmer, Waltham, MA, USA) with a polyethylene glycol capillary column (Zebron ZB-FFAP, $30 \mathrm{~m} \times 0.32 \mathrm{~mm}$ i.d., $0.5 \mu \mathrm{m}$ film thickness, Phenomenex LTD, Aschaffenburg, Germany) and a flame ionization detector.

Ammonia-N was analyzed using a steam distillation according to DIN38406-E5-2 within two hours after fluid sampling [28]. 


\subsubsection{Duodenal Chyme and Faeces Analyses}

After thawing, $2 \times 60 \mathrm{~mL}$ of each duodenal chyme sample were filled in $100 \mathrm{~mL}$ Kautex bottles. To ensure a representative proportion of solid and fluid components, the sub-sampling was done under constant stirring. The remainders of the duodenal chyme samples, as well as the pooled faeces samples were freeze dried (CHRIST, Osterode am Harz, Germany). Analysis of DM of duodenal chyme and faeces samples was performed according to VDLUFA method 3.1 [29]. Faeces samples were also analyzed for $\mathrm{aNDF}_{\mathrm{om}}$ and $\mathrm{ADF}_{\mathrm{om}}$. Furthermore, the $60 \mathrm{~mL}$ samples of duodenal chyme were used to determine the total nitrogen content according to Kjeldahl method (VDLUFA method 4.1.1) and the ammonia content according to DIN 38406-E5-2 [28,29]. The freeze dried samples of duodenal chyme and faeces were, besides, used to analyze the chromium concentration. For this, samples were prepared according to Williams et al. [30]. Chromium content of the freeze dried duodenal chyme and faeces samples was determined using an optical emission spectrometer with inductively coupled plasma (ICP-OES Quantima; GBC Scientific Equipment Pty. Ltd., Melbourne, VIC, Australia). The proportion of microbial nitrogen in duodenal chyme was determined at a wavelength of $800-2400 \mathrm{~nm}$ by using a NIR spectroscopy according to Lebzien and Paul [31].

\subsection{Calculations}

Computation of daily duodenal dry matter flow (DMF) was based on the equation according to Pappritz et al. [32]:

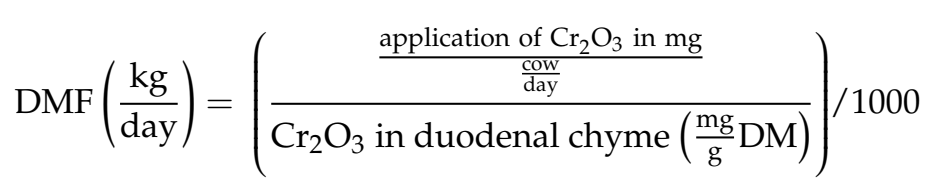

The following formulas were used to calculate non-ammonia-nitrogen (NAN) proportion at the duodenum:

$$
\begin{aligned}
& \text { Total } \mathrm{N} \text { in duodenal chyme }(\% \text { of } \mathrm{DM})=\frac{\text { Total } \mathrm{N}(\% \text { of fresh matter }(\mathrm{FM}))}{\mathrm{DM} \text { of duodenal chyme }(\%)} \times 100 \\
& \mathrm{NH}_{3} \mathrm{~N} \text { in duodenal chmye }(\% \text { of } \mathrm{DM})=\frac{\mathrm{NH}_{3} \mathrm{~N} \text { in duodenal chyme }(\% \text { of } \mathrm{FM})}{\mathrm{DM} \text { of duodenal chyme }(\%)} \times 100 \\
& \mathrm{NAN} \text { proportion in duodenal chyme }(\% \text { of } \mathrm{DM})=\text { Total } \mathrm{N} \text { in duodenal chyme } \\
& (\% \text { of } \mathrm{DM})-\mathrm{NH}_{3} \mathrm{~N} \text { in duodenal chyme }(\% \text { of } \mathrm{DM})
\end{aligned}
$$

Duodenal NAN flow $(\mathrm{kg} /$ day) was calculated by multiplying the NAN proportion in duodenal chyme (\% of DM) by DMF (kg/day).

The microbial crude protein $(\mathrm{mCP})$ was calculated using the following formula:

$$
\begin{gathered}
\mathrm{mCP}(\mathrm{g} / \text { day })=[\text { duodenal NAN flow }(\mathrm{kg} / \text { day }) \times(\text { microbial } \mathrm{N} \text { proportion of NAN } \\
(\%)) / 100] \times 6.25
\end{gathered}
$$

According to GfE [15] and Pappritz et al. [32] microbial organic matter (mOM), and ruminal fOM were calculated as follows:

$$
\operatorname{mOM}(\mathrm{kg} / \text { day })=11.8 \times \text { microbial } \mathrm{N}(\mathrm{kg} / \text { day })
$$

$\mathrm{fOM}(\mathrm{kg} /$ day $)=\mathrm{OM}$ intake $(\mathrm{kg} /$ day $)-[$ duodenal OM flow $(\mathrm{kg} /$ day $)-$ microbial OM (kg/day)]

Microbial efficiency was calculated as mCP per fOM according to GfE [15]. 
Digestibility quotient of $\mathrm{aNDF}_{\mathrm{om}}$ and $\mathrm{ADF}_{\mathrm{om}}$ was calculated according to Simon [33] for the total digestive tract and at the duodenum. An example for the calculation is given for digestibility of $\mathrm{aNDF}_{\mathrm{om}}$ at the duodenum.

digestibility quotient of aNDFom $(\%)=[($ aNDFom intake $(\mathrm{kg} /$ day $)-$ aNDFom at the duodenum(kg/day))/aNDFom intake $(\mathrm{kg} /$ day $)] \times 100$

The equation according to McGinn et al. [34] was used to calculate total digestive tract digestibility of DM (tdDM):

$$
\begin{gathered}
\operatorname{tdDM}(\%)=1-\left[\left(\mathrm{Cr}_{2} \mathrm{O}_{3} \text { in marker }(\mathrm{mg} / \text { day })\right) / \mathrm{DM} \text { intake }(\mathrm{kg} / \text { day })\right] / \mathrm{Cr}_{2} \mathrm{O}_{3} \text { in faeces } \\
\times(\mathrm{mg} / \mathrm{kg} \times \mathrm{DM})
\end{gathered}
$$

\subsection{Statistical Analysis}

For ruminal $\mathrm{pH}$ data were summarized to means of every measuring period for each cow and hence weekly means were calculated.

Weekly means were also calculated for performance parameters, milk parameters and proportion of SCFA and ammonia concentration in rumen fluid. For statistical analyses, two weeks were merged to one period for every parameter, which resulted in five periods.

For statistical analyses of duodenal chyme samples, mean values for the five sampling days were calculated for each cow and each parameter.

The statistical evaluation with the SAS software package (version 9.4.; SAS Institute Inc., Cary, NC, USA) included the data collected after parturition when cows received different diets. Performance parameters, proportion of SCFA and ammonia concentration values in rumen fluid, as well as rumen $\mathrm{pH}$ parameters were analyzed by using the MIXED procedure for repeated measures with a compound symmetry structure [35]. C and period were applied as fixed effects, as well as the interaction between them. Each cow within treatment was considered to be a random effect. The period of sampling was treated as a repeated measure.

For the analysis of the duodenal chyme samples with regard to the estimated parameters, we wanted to assess both the effect of rations differing in C, as well as individually different microbial efficiencies (defined as $\mathrm{mCP} / \mathrm{fOM}$, according to GfE [15]) concerning nutrients flows, digestibilities, and ruminal $\mathrm{pH}$. As duodenal chyme was sampled in only one period, the statistical evaluation included just a simple t-test with two different grouping strategies. First, concentrate feed proportion $\left(C_{60}\right.$ vs. $\left.C_{35}\right)$ was used for grouping. Secondly, cows were grouped according to microbial efficiency (more and less efficient, see Figure 1). For this, the mean microbial efficiency of $156 \mathrm{~g} \mathrm{mCP} / \mathrm{kg} \mathrm{fOM}$ according to GfE [15] was used as threshold. Cows with an individual microbial efficiency $<156 \mathrm{~g} / \mathrm{kg}$ were considered to be less efficient, whereas cows with an individual microbial efficiency $>156 \mathrm{~g} / \mathrm{kg}$ were considered to be more efficient. The individual microbial efficiencies for the week of duodenal chyme sampling are presented in Table A2. The statistical evaluations with either C or microbial efficiency as fixed factors are presented in Figure 1. 


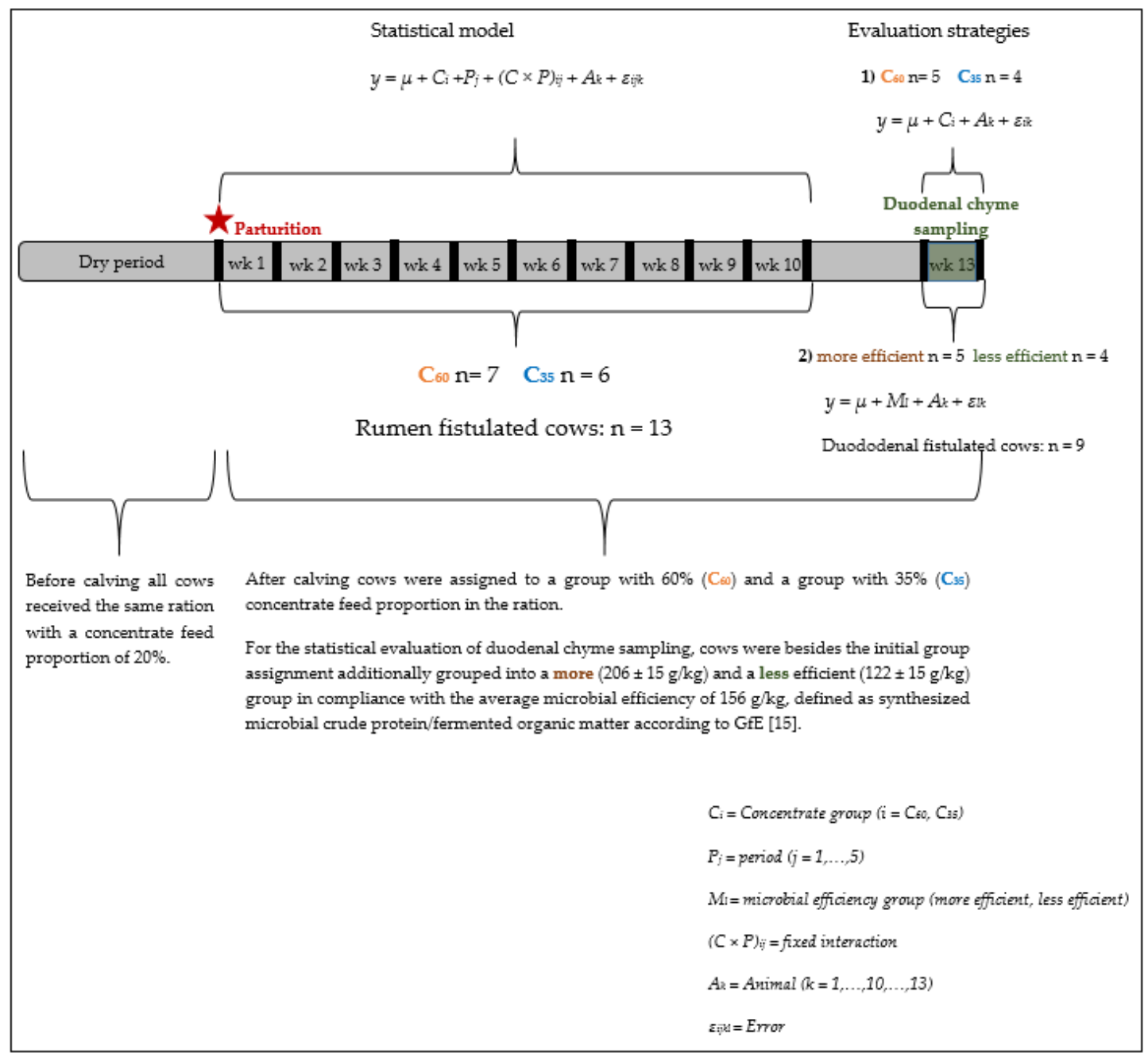

Figure 1. Experimental setup and statistical evaluations.

By assessing Pearson's correlation coefficient, we examined relations between parameters applying the statistical software TIBCO Statistica (Version 13.3, TIBCO Software Inc., Palo Alto, CA, USA) for both approaches. Furthermore, we performed linear regression analysis, if suitable.

The MIXED procedure, the $t$-Test and the correlation coefficient $(r)$ were considered statistically significant when $p \leq 0.05$ and highly significant when $p \leq 0.01$ while a trend was assumed for $0.05<p<0.1$.

In the following, results are presented as LSMean \pm standard error of means (SEM) for the MIXED procedure, and as means \pm standard deviation of means (SD) for the $t$-Test, unless otherwise stated.

To analyze the diurnal ruminal $\mathrm{pH}$ variation, the values $\beta 0$ and $\beta 1$ were estimated by using PROC NLMIXED in SAS 9.4 (version 9.4; SAS Institute Inc., Cary, NC, USA). A logistic curve was fitted for every 24 hour interval, whereby $\beta 0$ illustrates the slope of the regression line at the inflection point and therefore displays the variation of rumen $\mathrm{pH}$ over $24 \mathrm{~h}$ (the greater the values the more constant the ruminal $\mathrm{pH}$ ) while $\beta 1$ represents the inflection point of the curve and is an indicator for the average $\mathrm{pH}$ of the $24 \mathrm{~h}$ period [36]. The logistic curve depends on three parameters, namely the slope ( $\beta 0)$ of the upper limit $(\beta 2)$ and the inflection point $(\beta 1)$ of the curve. The following formula describes this association:

$$
\mathrm{y}=\frac{\beta 2}{1+\exp \times[-\beta 0 \times(x-\beta 1)]}
$$

The accumulated time (min/day) spent below each corresponding $\mathrm{pH}$ point on the $\mathrm{x}$-axis, is represented on the $y$-axis. The ruminal $\mathrm{pH}$ values are represented on the $\mathrm{x}$-axis. The upper limit of the 
curve was kept constant at 1,440 min/day. Therefore, the logistic curve is only described by $\beta 0$ and $\beta 1$ Colman et al. [37].

The time per day with $\mathrm{pH}<5.8$ (min/day) was evaluated as described in Colman et al. [37]. Thresholds of 5.24 hours/day at $\mathrm{pH}<5.8$ and a daily average $\mathrm{pH}<6.16$ were set for a higher SARA risk according to Zebeli et al. (2008). For assessing the SARA risk, a SARA risk -Score was calculated for which the following equation according to Schären et al. [38] was used.

$$
\text { SARA }_{\text {risk }}-\text { Score }=\frac{\sum\left(\frac{\text { Number of positive observations per cow in period } i}{\text { Total number of observations per cow in period } i}\right)}{\text { Total number of cows assessed in period } i}
$$

For the intergroup comparison, weekly means of each parameter were calculated.

\section{Results}

\subsection{Performance Parameters}

DMI increased over time irrespective of concentrate feed proportion of the ration ( $p_{\text {period }}<0.001$, Table A1). Net energy intake, as well as starch intake increased over time more pronounced in group $\mathrm{C}_{60}$ compared to $\mathrm{C}_{35}$. $\left(p_{\text {Cxperiod }}\right.$ net energy intake $=0.016$, Table A1, $p_{\text {Cxperiod }}$ starch intake $<0.001$, Table A1).

Milk yield increased over time in both groups, with a steeper rise in group $C_{35}$, but an approximation of group $C_{60}$ to group $C_{35}$ during the last part of the trial ( $\left.p_{C \times \text { period }}<0.001\right)$. Energy corrected milk tended to be higher for the $C_{35}$ group $\left(p_{C}=0.093\right)$ and enhanced within each group over the trial $\left(p_{\text {period }}<0.001\right)$. Milk fat content enhanced in both groups, with a more pronounced increase in group $\mathrm{C}_{35}\left(p_{\text {Cxperiod }}<0.001\right)$. The same is true for milk fat yield $\left(p_{\text {Cxperiod }}=0.042\right)$. Milk protein content increased in both groups during the trial, without any group differences ( $\left.p_{\text {period }}<0.001\right)$. The same is true for milk protein yield $\left(p_{\text {period }}<0.001\right)$ and lactose concentration $\left(p_{\text {period }}=0.002\right)$. Milk lactose yield increased more pronouncedly in group $C_{60}$ compared to $C_{35}\left(p_{C x p e r i o d}<0.001\right)$. In contrast, milk fat:protein ratio decreased in both groups, but remained more stable in group $C_{35}$ over time $\left(p_{\mathrm{C} x p e r i o d}\right.$ $=0.002)$. (The appropriate results are shown in Table A1).

\section{2. $p H$ Parameters}

We determined different $\mathrm{pH}$ parameters in order to describe the conditions in the rumen. For the SARA defining thresholds according to Zebeli et al. [9], including the daily mean $\mathrm{pH}$ (Figure 2A, Table 3) and the time per day with $\mathrm{pH}<5.8$ (Figure 2B, Table 3) we could not prove any significant effects between the two trial groups receiving different concentrate proportions. Regarding the $\mathrm{SARA}_{\text {risk }}$-Score (Figure 2C, Table 3), values for the $\mathrm{C}_{60}$ group ranged between 0.33 and $0.86( \pm 0.17 \mathrm{SD})$. The $\mathrm{C}_{35}$ group reached values between 0.36 and $0.57( \pm 0.08 \mathrm{SD})$. 


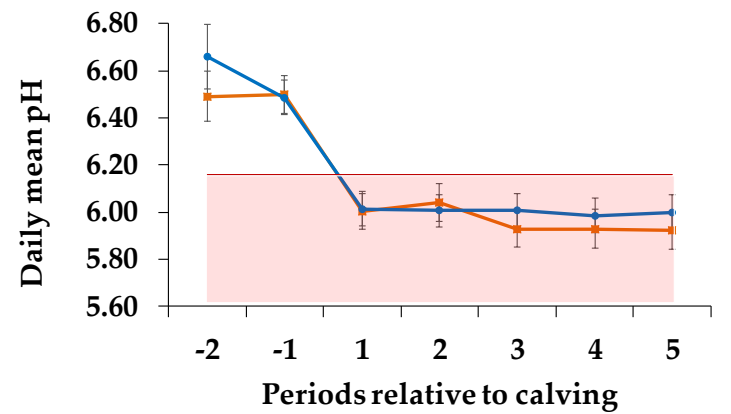

(A)

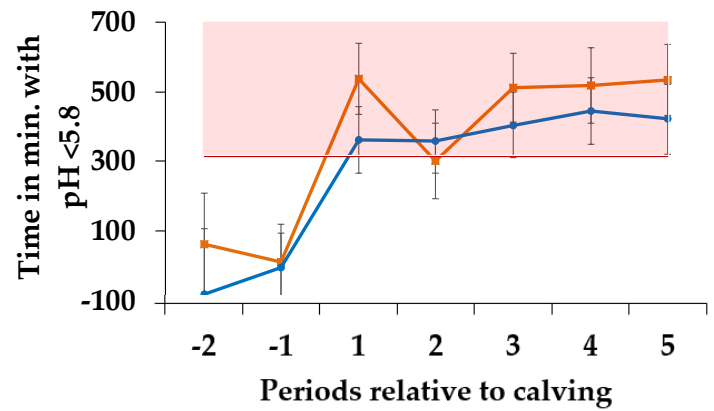

(B)

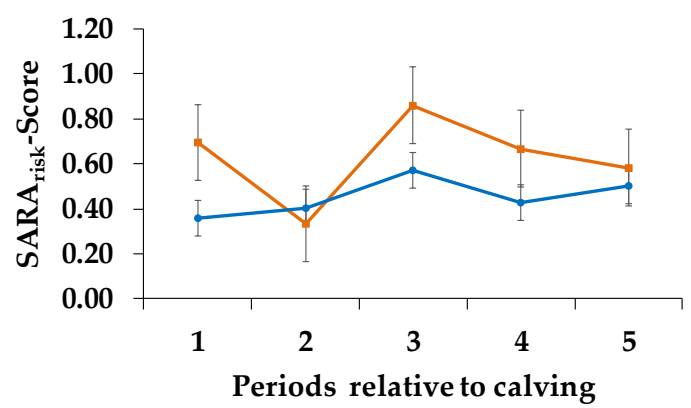

(C)

Figure 2. Daily mean $\mathrm{pH}$ of the rumen (A), time per day with $\mathrm{pH}<5.8$ (B) from week 3 antepartum until week 10 postpartum; red areas indicate SARA risk. Statistical analysis started at calving (period 1: weeks 1-2 postpartum, period 2: weeks 3-4 postpartum, period 3: weeks 5-6 postpartum, period 4: weeks 7-8 postpartum and period 5: weeks 9-10 postpartum) and $\mathrm{SARA}_{\text {risk }}-\mathrm{Score}(\mathrm{C})$ was calculated as quotient of the sum of the number of positive observations per cow in period $i$ and total number of observations per cow in period $i$ divided by total number of cows assessed in period $i$, during period 1-5 in the treatment groups. After calving, cows were assigned to a group with $60 \%$ concentrate feed proportion (increasing from 35 to $60 \%$ during the first three weeks after parturition, $\mathrm{C}_{60}$, orange, $\mathrm{n}=6$ ) and a group with $35 \%$ concentrate feed proportion $\left(C_{35}\right.$, blue, $\left.n=7\right)$ in the ration.

Table 3. $p$-values of effects of concentrate proportion of the diet (C), period and the interaction between them on daily mean $\mathrm{pH}$ and time in minutes with $\mathrm{pH}<5.8$.

\begin{tabular}{cccc}
\hline & \multicolumn{3}{c}{$p$-Values } \\
\cline { 2 - 4 } & $\mathrm{C}$ & Period $\$$ & $\mathrm{C} \times$ Period \\
\hline (A) Daily mean $\mathrm{pH}$ & 0.700 & 0.506 & 0.724 \\
(A) Time in min. with $\mathrm{pH}<5.8$ & 0.557 & 0.205 & 0.545 \\
\hline
\end{tabular}

After calving, cows were assigned to a group with $60 \%$ concentrate feed proportion (increasing from 35 to $60 \%$ during the first three weeks after parturition, $\left.C_{60}, n=6\right)$ and a group with $35 \%$ concentrate feed proportion $\left(C_{35}, n=7\right)$ in the ration. § Period 1: weeks 1-2 postpartum, period 2: weeks 3-4 postpartum, period 3: weeks 5-6 postpartum, period 4: weeks 7-8 postpartum and period 5: weeks 9-10 postpartum.

$C(p=0.099)$ tended to affect $\beta 0$ (Figure 3A, Table 4$)$, as the group with the lower $C$ exhibited higher values and thus had lower $\mathrm{pH}$ variations over the day. 


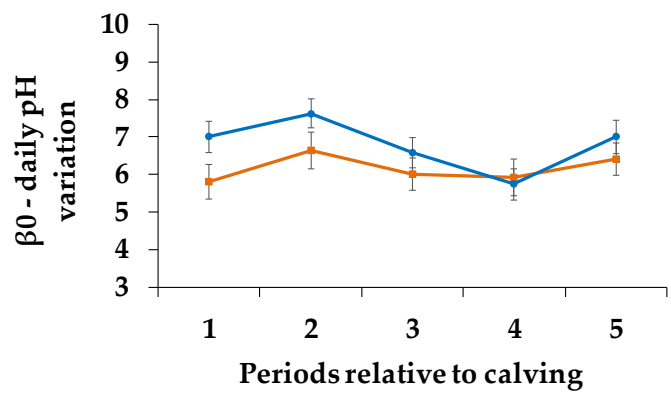

(A)

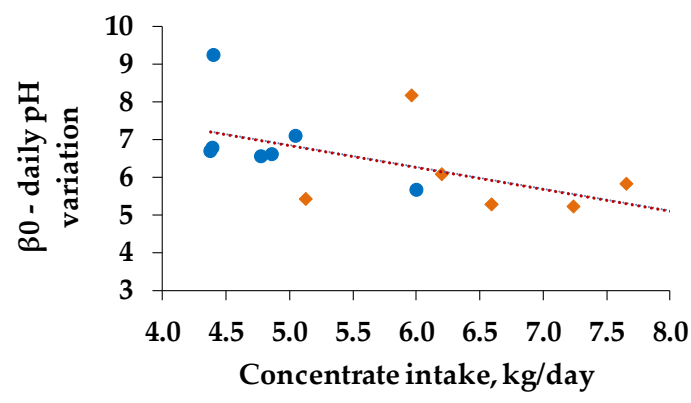

(B)

Figure 3. $\beta 0$ (A: illustrates the slope of the regression line at the inflection point and therefore displays the variation of rumen $\mathrm{pH}$ over $24 \mathrm{~h}$; the greater the values the more constant the ruminal $\mathrm{pH}$ ) during period 1 (weeks 1-2 postpartum), period 2 (weeks 3-4 postpartum), period 3 (weeks 5-6 postpartum), period 4 (weeks 7-8 postpartum) and period 5 (weeks 9-10 postpartum) as well as regression of $\beta 0$ and actual concentrate intake in period $1\left(\mathbf{B}: \mathrm{y}=-0.558 \mathrm{x}+9.589, \mathrm{r}^{2}=0.311, \mathrm{p}<0.05\right)$ for each individual cow in period 1 . After calving, cows were assigned to a group with $60 \%$ concentrate feed proportion (increasing from 35 to $60 \%$ during the first three weeks after parturition, $C_{60}$, orange, $n=6$ ) and a group with $35 \%$ concentrate feed proportion $\left(C_{35}\right.$, blue, $\left.n=7\right)$ in the ration.

Table 4. $p$-values of effects of concentrate proportion of the diet (C), period and the interaction between them on daily $\mathrm{pH}$ variation $(\beta 0)$.

\begin{tabular}{cccc}
\hline & \multicolumn{3}{c}{$p$-Values } \\
\cline { 2 - 4 } & $\mathbf{C}$ & Period $^{\S}$ & $\mathrm{C} \times$ Period \\
\hline (A) $\beta 0^{\$}$ & 0.099 & 0.032 & 0.517 \\
\hline
\end{tabular}

$\$ \beta 0$ illustrates the slope of the regression line at the inflection point and therefore displays the variation of rumen $\mathrm{pH}$ over $24 \mathrm{~h}$; the greater the values the more constant the ruminal $\mathrm{pH}$. After calving, cows were assigned to a group with $60 \%$ concentrate feed proportion (increasing from 35 to $60 \%$ during the first three weeks after parturition, $\left.C_{60}, n=6\right)$ and a group with $35 \%$ concentrate feed proportion $\left(C_{35}, n=7\right)$ in the ration. ${ }^{\S}$ Period 1 : weeks $1-2$ postpartum, period 2: weeks 3-4 postpartum, period 3: weeks 5-6 postpartum, period 4: weeks 7-8 postpartum and period 5: weeks $9-10$ postpartum.

$\beta 0$ increased during the first part of the trial to decrease during period 3 and 4 , with a second peak in period 5 in both groups $(p=0.032)$. However, none of the factors affected $\beta 1$ (Table 5).

Table 5. Effects of concentrate feed proportion in the diet (C) and of period $\beta 1$ (describes the inflection point of the curve and represents the average $\mathrm{pH}$ of the $24 \mathrm{~h}$ period) during period 1 (weeks 1-2 postpartum), period 2 (weeks 3-4 postpartum), period 3 (weeks 5-6 postpartum), period 4 (weeks 7-8 postpartum) and period 5 (weeks $9-10$ postpartum) comparing the treatment groups.

\begin{tabular}{|c|c|c|c|c|c|c|}
\hline \multirow{2}{*}{ Item } & \multicolumn{2}{|c|}{ Grouping § } & \multirow{2}{*}{ SEM \# } & \multicolumn{3}{|c|}{$p$-Value } \\
\hline & $\begin{array}{c}C_{60} \\
n=6\end{array}$ & $\begin{array}{c}\mathrm{C}_{35} \\
\mathrm{n}=7\end{array}$ & & $\mathrm{C}$ & Period & $\mathrm{C} \times$ Period \\
\hline$\beta 1$ & & & & & & \\
\hline Period 1 & 5.93 & 6.02 & 0.08 & 0.654 & 0.306 & 0.668 \\
\hline Period 2 & 6.07 & 6.02 & & & & \\
\hline Period 3 & 5.96 & 6.01 & & & & \\
\hline Period 4 & 5.92 & 5.98 & & & & \\
\hline Period 5 & 5.94 & 5.99 & & & & \\
\hline
\end{tabular}

$\S$ After calving cows were assigned to a group with $60 \%$ concentrate feed proportion (increasing from 35 to $60 \%$ during the first three weeks after parturition, $\left.\mathbf{C}_{60}\right)$ and a group with $35 \%$ concentrate feed proportion $\left(\mathbf{C}_{35}\right)$ in the ration. Values are presented as least square means. " Pooled standard error of means. 
When assessing the results of $\beta 1$ on an individual basis (Figure 4) it also becomes apparent that animals within the same group differ. Both groups contain cows with lower or higher levels of average $\mathrm{pH}$.

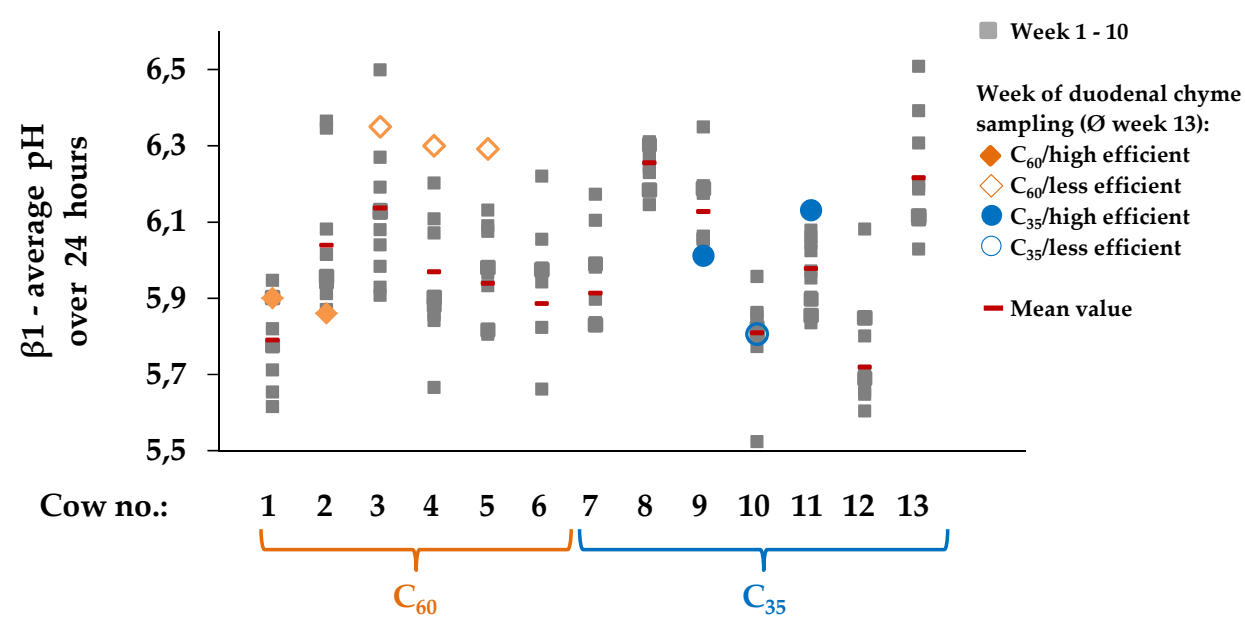

Figure 4. $\beta 1$ (describing the inflection point of the curve and representing the average $\mathrm{pH}$ of the $24 \mathrm{~h}$ period) for individual cows and each of the 10 experimental weeks as well as of the week of duodenal chyme sampling (on average week 13 p.p. \pm 16 days)) reflecting the individual variability independent of grouping. After calving cows were assigned to a group with $60 \%$ concentrate feed proportion (increasing from 35 to $60 \%$ during the first three weeks after parturition, $C_{60}$, orange, $n=6$ ) and a group with $35 \%$ concentrate feed proportion $\left(C_{35}\right.$, blue, $\left.n=7\right)$ in the ration. For the week of duodenal chyme sampling, cows were additionally grouped into a more $(\bullet / \diamond$ filled, $206 \pm 17 \mathrm{~g} / \mathrm{kg}, \mathrm{n}=5)$ and a less efficient $(\circlearrowleft / \diamond$, blank, $122 \pm 17 \mathrm{~g} / \mathrm{kg}, \mathrm{n}=4)$ group in compliance with the average microbial efficiency of $156 \mathrm{~g} / \mathrm{kg}$ defined as synthesized microbial crude protein/fermented organic matter according to GfE [15].

\subsection{Short Chain Fatty Acids}

Increase of total volatile fatty acids (Table 6) was observed in both groups over the trial $\left(p_{\text {period }}=0.020\right)$. Acetic acid (Table 6) tended to increase more pronounced in group $\mathrm{C}_{35}$ compared to $\mathrm{C}_{60}$ over time $\left(p_{\mathrm{C}} \times\right.$ period $\left.=0.053\right)$. In contrast, propionic acid (Table 6$)$ increased more pronounced in group $\mathrm{C}_{60}$ and decreased in group $\mathrm{C}_{35}$ during the last part of the trial $\left(p_{\mathrm{C}} \times\right.$ period $\left.=0.064\right)$. Butyric acid (Table 6) decreased over time without any differences between groups $\left(p_{\text {period }}=0.001\right)$. For acetate:propionate ratio (Table 6), both groups achieved the highest values in period 1. Values then decreased during the first half of the study and increased again during the last part $\left(p_{\text {period }}<0.001\right)$. 
Table 6. Effects of concentrate feed proportion in the diet (C) and period on short chain fatty acids, as well as on acetate:propionate ratio and ammonia-nitrogen (ammonia-N) concentration during period 1 (weeks 1-2 postpartum), period 2 (weeks 3-4 postpartum), period 3 (weeks 5-6 postpartum), period 4 (weeks 7-8 postpartum) and period 5 (weeks 9-10 postpartum) in the treatment groups.

\begin{tabular}{|c|c|c|c|c|c|c|}
\hline \multirow{2}{*}{ Item } & \multicolumn{2}{|c|}{ Grouping $\S$} & \multirow{2}{*}{ SEM $^{\#}$} & \multicolumn{3}{|c|}{$p$-Value } \\
\hline & $\begin{array}{c}C_{60} \\
n=6\end{array}$ & $\begin{array}{c}\mathrm{C}_{35} \\
\mathrm{n}=7\end{array}$ & & $\mathrm{C}$ & Period & $\mathrm{C} \times$ period \\
\hline \multicolumn{7}{|c|}{ Total short chain fatty acids, mmol/L } \\
\hline Period 1 & 76.1 & 71.1 & 5.7 & 0.883 & 0.020 & 0.107 \\
\hline Period 2 & 79.7 & 73.5 & & & & \\
\hline Period 3 & 72.9 & 90.3 & & & & \\
\hline Period 4 & 94.8 & 83.5 & & & & \\
\hline Period 5 & 79.5 & 80.7 & & & & \\
\hline \multicolumn{7}{|c|}{ Acetic acid, Mol\% } \\
\hline Period 1 & 56.9 & 57.9 & 1.8 & 0.117 & 0.001 & 0.053 \\
\hline Period 2 & 51.5 & 56.6 & & & & \\
\hline Period 3 & 53.4 & 54.1 & & & & \\
\hline Period 4 & 50.6 & 57.3 & & & & \\
\hline Period 5 & 53.4 & 56.3 & & & & \\
\hline \multicolumn{7}{|c|}{ Propionic acid, $\mathrm{Mol} \%$} \\
\hline Period 1 & 23.7 & 22.9 & 1.7 & 0.053 & $<0.001$ & 0.064 \\
\hline Period 2 & 29.5 & 25.3 & & & & \\
\hline Period 3 & 29.2 & 27.3 & & & & \\
\hline Period 4 & 32.6 & 25.5 & & & & \\
\hline Period 5 & 31.3 & 25.9 & & & & \\
\hline \multicolumn{7}{|c|}{ Butyric acid, Mol\% } \\
\hline Period 1 & 14.7 & 14.9 & 0.9 & 0.224 & 0.001 & 0.422 \\
\hline Period 2 & 13.5 & 13.3 & & & & \\
\hline Period 3 & 12.1 & 13.8 & & & & \\
\hline Period 4 & 11.9 & 13.0 & & & & \\
\hline Period 5 & 10.9 & 13.1 & & & & \\
\hline \multicolumn{7}{|c|}{ Acetate:propionate ratio } \\
\hline Period 1 & 2.49 & 2.63 & 0.22 & 0.103 & $<0.001$ & 0.131 \\
\hline Period 2 & 1.82 & 2.33 & & & & \\
\hline Period 3 & 1.90 & 2.04 & & & & \\
\hline Period 4 & 1.57 & 2.34 & & & & \\
\hline Period 5 & 1.73 & 2.30 & & & & \\
\hline
\end{tabular}

\subsection{Evaluations of The Week of Duodenal Chyme Sampling by Different Statistical Evaluations}

\subsubsection{Microbial Efficiency, $\mathrm{pH}$ Parameters, Nutrient Flows and Digestibiliy at the Duodenum}

For the analysis of the estimated parameters in the duodenal chyme samples, we wanted to assess both the effect of rations differing in $\mathrm{C}$, as well as individually different microbial efficiencies. For this, different statistical evaluations were applied and cows were assigned to different $C$ according to the initial experimental design and additionally grouped according to microbial efficiency ( $\mathrm{mCP} / \mathrm{fOM}$, more and less efficient). This attempt was made in order to gain more information about the relation between $\mathrm{pH}$ parameters and microbial efficiency, as well as on parameter such as nutrient flows and digestibility.

\subsection{2. $\mathrm{pH}$ Parameters}

We compared daily mean $\mathrm{pH}$, time per day with $\mathrm{pH}<5.8$, as well as $\beta 0$ and $\beta 1$ during the week of duodenal sampling between the $\mathrm{C}_{60}$ and $\mathrm{C}_{35}$ groups, as well as between more and less efficient groups. However, we could not detect any significant differences (Table 7). 
In this trial, concentrate had no significant effect on $\mathrm{mCP}$, fOM or $\mathrm{mCP} / \mathrm{fOM}$ (Table 8).

The same is true for DMF, organic matter flow (OMF) and rumen ammonia-N (Table 8).

$\mathrm{mCP}$ (Table 8) tended to be higher for the more efficient group compared to the less efficient group $\left(p_{\mathrm{mCP} / \mathrm{fOM}}=0.081\right)$. FOM (Table 8$)$ was significantly higher for less efficient groups $\left(p_{\mathrm{mCP} / \mathrm{fOM}}=0.024\right)$. $\mathrm{mCP} / \mathrm{fOM}$ was significantly higher for more efficient animals $\left(p_{\mathrm{mCP} / \mathrm{fOM}}<0.001\right)$. For DMF (Table 8$)$, as well as for duodenal organic matter flow (OMF, Table 8), we detected a significant difference between groups $\left(p_{\mathrm{mCP} / \mathrm{fOM}} \mathrm{DMF}=0.032, p_{\mathrm{mCP} / \mathrm{fOM}} \mathrm{OMF}=0.037\right)$ as more efficient groups had higher values in both parameters.

Rumen ammonia-N (Table 8) did not differ between groups.

\subsubsection{Digestibility}

We assessed both the total digestive tract digestibility of dry matter (tdDM) and the digestibility at the duodenum. None of the nutrient digestibilities at the duodenum (Table 9) was influenced by C. 
Table 7. Effects of concentrate feed proportion in the ration $(\mathrm{C})$ and microbial efficiency (synthesized microbial crude protein/fermented organic matter) on ruminal $\mathrm{pH}$ parameters.

\begin{tabular}{|c|c|c|c|c|c|c|c|c|}
\hline \multirow{2}{*}{ Item $^{+}$} & \multicolumn{2}{|c|}{ Grouping Model $1{ }^{\$}$} & \multirow{2}{*}{$\mathrm{SD}^{\#}$} & \multirow{2}{*}{$p$-Value } & \multicolumn{2}{|c|}{ Grouping Model $2 \S$} & \multirow{2}{*}{$\mathrm{SD}^{\#}$} & \multirow{2}{*}{$p$-Value } \\
\hline & $\begin{array}{c}\mathrm{C}_{60} \\
\mathrm{n}=5\end{array}$ & $\begin{array}{c}C_{35} \\
n=4\end{array}$ & & & $\begin{array}{c}\text { More Efficient } \\
n=5\end{array}$ & $\begin{array}{c}\text { Less Efficient } \\
n=4\end{array}$ & & \\
\hline Daily mean $\mathrm{pH}$ & 6.01 & 6.08 & 0.20 & 0.674 & 6.00 & 6.06 & 0.21 & 0.700 \\
\hline Time in min. with $\mathrm{pH}<5.8$ & 445 & 266 & 250 & 0.400 & 395 & 361 & 288 & 0.873 \\
\hline$\beta 0^{*}$ & 6.09 & 5.54 & 0.87 & 0.391 & 5.84 & 5.93 & 0.85 & 0.893 \\
\hline$\beta 1^{+}$ & 6.14 & 5.98 & 0.20 & 0.359 & 5.98 & 6.19 & 0.19 & 0.186 \\
\hline
\end{tabular}

+ Intergroup comparison for the week of duodenal chyme sampling (on average week 13 postpartum \pm 16 days) - for both assignments $\left(\mathbf{C}_{60}\right.$ vs. $\mathbf{C}_{35}$, more vs. less efficient, respectively).

$\$$ After calving cows were assigned to a group with $60 \%$ (increasing from 35 to $60 \%$ during the first three weeks after parturition, $C_{60}$ ) in the ration and a group with $35 \%$ concentrate feed proportion $\left(C_{35}\right)$. \& For the week of duodenal chyme sampling cows were additionally grouped into a more $(206 \pm 17 \mathrm{~g} / \mathrm{kg}, \mathrm{n}=5)$ and a less efficient $(122 \pm 17 \mathrm{~g} / \mathrm{kg}$, $\mathrm{n}=4)$ group according proportion $\left(C_{35}\right) .8$ For the week of duodenal chyme sampling cows were additionally grouped into a more $(206 \pm 17 \mathrm{~g} / \mathrm{kg}, \mathrm{n}=5)$ and a less efficient $(122 \pm 17 \mathrm{~g} / \mathrm{kg}, \mathrm{n}=4)$ group according
to the mean microbial efficiency of $156 \mathrm{~g} / \mathrm{kg}$, defined as synthesized microbial crude protein/fermented organic matter in compliance with GfE [15]. ${ }^{*}$ illustrates the slope of the regression to the mean microbial efficiency of $156 \mathrm{~g} / \mathrm{kg}$, defined as synthesized microbial crude protein/fermented organic matter in compliance with GfE [15]. illustrates the slope of the regression
line at the inflection point and therefore displays the variation of rumen $\mathrm{pH}$ over $24 \mathrm{~h}$; the greater the values the more constant the ruminal $\mathrm{pH}$. ${ }^{\dagger}$ describes the inflection point of the curve and represents the average $\mathrm{pH}$ of the $24 \mathrm{~h}$ period. Values are presented as means, ${ }^{\#}$ Pooled standard deviation.

Table 8. Effects of concentrate feed proportion in the ration (C) and microbial efficiency (synthesized microbial crude protein/fermented organic matter) on synthesized microbial crude protein $(\mathrm{mCP})$, fermented organic matter $(\mathrm{fOM})$ and microbial efficiency $(\mathrm{mCP} / \mathrm{fOM})$, and on duodenal nutrient flows and nitrogen sources, and on ruminal nitrogen balance $(\mathrm{RNB})$.

\begin{tabular}{|c|c|c|c|c|c|c|c|c|}
\hline \multirow{2}{*}{ Item $^{+}$} & \multicolumn{2}{|c|}{ Grouping Model $1^{\$}$} & \multirow{2}{*}{$\mathrm{SD}^{\#}$} & \multirow{2}{*}{$p$-Value } & \multicolumn{2}{|c|}{ Grouping Model $2 \S$} & \multirow{2}{*}{$\mathrm{SD}^{\#}$} & \multirow{2}{*}{$p$-Value } \\
\hline & $\begin{array}{c}\mathrm{C}_{60} \\
\mathrm{n}=5\end{array}$ & $\begin{array}{c}\mathrm{C}_{35} \\
\mathrm{n}=4\end{array}$ & & & $\begin{array}{l}\text { More Efficient } \\
\quad \mathrm{n}=5\end{array}$ & $\begin{array}{c}\text { Less Efficient } \\
n=4\end{array}$ & & \\
\hline Microbial crude protein, g/day & 2129 & 2280 & 409 & 0.806 & 2479 & 1922 & 356 & 0.081 \\
\hline Fermented organic matter, kg/day & 14.4 & 12.9 & 3.0 & 0.457 & $12.1^{\mathrm{B}}$ & $15.8^{\mathrm{A}}$ & 2.1 & 0.034 \\
\hline Microbial crude protein/fermented organic matter, $\mathrm{g} / \mathrm{kg}$ & 155 & 186 & 47 & 0.355 & $206^{\mathrm{A}}$ & $122^{\mathrm{B}}$ & 17 & $<0.001$ \\
\hline Duodenal dry matter flow, $\mathrm{kg} /$ day & 15.8 & 15.9 & 2.9 & 0.954 & $17.7^{\mathrm{A}}$ & $13.6^{\mathrm{B}}$ & 2.2 & 0.032 \\
\hline Duodenal organic matter flow, $\mathrm{kg} /$ day & 13.6 & 13.5 & 2.6 & 0.956 & $15.1^{\mathrm{A}}$ & $11.7^{\mathrm{B}}$ & 2.0 & 0.037 \\
\hline Rumen ammonia- $\mathrm{N}^{*}, \mathrm{mg} / 100 \mathrm{~g}$ & 3.0 & 7.5 & 4.0 & 0.176 & 5.12 & 5.44 & 3.95 & 0.932 \\
\hline
\end{tabular}

+ Intergroup comparison for the week of duodenal chyme sampling (on average week 13 postpartum \pm 16 days) - for both assignments $\left(\mathbf{C}_{60}\right.$ vs. $\mathbf{C}_{35}$, more vs. less efficient, respectively). ${ }_{\mathrm{AB}}$ least square means with different superscripts differ within row. \$ After calving cows were assigned to a group with $60 \%$ (increasing from $35-60 \%$ during the first three weeks after parturition, $\left.\mathbf{C}_{60}\right)$ in the ration and a group with $35 \%$ concentrate feed proportion $\left(\mathbf{C}_{35}\right)$. $\$$ For the week of duodenal chyme sampling cows were additionally grouped into a more $(206 \pm 17 \mathrm{~g} / \mathrm{kg}, \mathrm{n}=5)$ and a less efficient $(122 \pm 17 \mathrm{~g} / \mathrm{kg}, \mathrm{n}=4)$ group according to the mean microbial efficiency of $156 \mathrm{~g} / \mathrm{kg}$, defined as synthesized microbial crude protein/fermented organic matter in compliance with GfE [15]. * Nitrogen. Values are presented as means, \# Pooled standard deviation. 
Table 9. Effect of concentrate feed proportion of the ration and microbial efficiency (synthesized microbial crude protein/fermented organic matter) on apparent nutrient digestibility at the duodenum and the total digestive tract digestibility at faecal level.

\begin{tabular}{|c|c|c|c|c|c|c|c|c|}
\hline \multirow{2}{*}{ Item $^{+}$} & \multicolumn{2}{|c|}{ Grouping Model $1^{\$}$} & \multirow{2}{*}{$\mathrm{SD}^{\#}$} & \multirow{2}{*}{$p$-Value } & \multicolumn{2}{|c|}{ Grouping Model $2 \S$} & \multirow{2}{*}{$\mathrm{SD}^{\#}$} & \multirow{2}{*}{$p$-Value } \\
\hline & $\begin{array}{c}\mathrm{C}_{60} \\
\mathrm{n}=5\end{array}$ & $\begin{array}{c}\mathrm{C}_{35} \\
\mathrm{n}=4\end{array}$ & & & $\begin{array}{l}\text { More Efficient } \\
\quad n=5\end{array}$ & $\begin{array}{c}\text { Less Efficient } \\
n=4\end{array}$ & & \\
\hline \multicolumn{9}{|c|}{ Duodenal nutrient digestibility, \% } \\
\hline Neutral detergent fiber & 37 & 40 & 12 & 0.750 & 32 & 46 & 11 & 0.086 \\
\hline Acid detergent fiber & 31 & 35 & 13 & 0.711 & 27 & 40 & 12 & 0.144 \\
\hline Organic matter & 43 & 38 & 10 & 0.490 & $33^{\mathrm{B}}$ & $51^{\mathrm{A}}$ & 5 & 0.001 \\
\hline \multicolumn{9}{|c|}{ Total digestive tract nutrient digestibility, $\%$} \\
\hline Neutral detergent fiber & 46 & 42 & 6 & 0.298 & $41^{\mathrm{B}}$ & $49^{\mathrm{A}}$ & 4 & 0.036 \\
\hline Acid detergent fiber & 40 & 35 & 6 & 0.338 & $34^{\mathrm{B}}$ & $43^{\mathrm{A}}$ & 4 & 0.017 \\
\hline Organic matter & $67^{\mathrm{A}}$ & $60^{\mathrm{B}}$ & 4 & 0.003 & $61^{\mathrm{B}}$ & $68^{\mathrm{A}}$ & 3 & 0.027 \\
\hline
\end{tabular}

${ }^{+}$Intergroup comparison for the week of duodenal chyme sampling (on average week 13 postpartum \pm 16 days), for both assignments $\left(\mathbf{C}_{60}\right.$ vs. $\mathbf{C}_{35}$, more vs. less efficient, respectively) $\mathrm{AB}$ least square means with different superscripts differ within row. \$ After calving cows were assigned to a group with $60 \%$ (increasing from $35-60 \%$ during the first three weeks after parturition, $\left.\mathbf{C}_{60}\right)$ in the ration and a group with $35 \%$ concentrate feed proportion $\left(\mathbf{C}_{35}\right)$. ${ }^{\S}$ For the week of duodenal chyme sampling cows were additionally grouped into a more $(206 \pm 17 \mathrm{~g} / \mathrm{kg}, \mathrm{n}=5)$ and a less efficient $(122 \pm 17 \mathrm{~g} / \mathrm{kg}, \mathrm{n}=4)$ group according to the mean microbial efficiency of $156 \mathrm{~g} / \mathrm{kg}$, defined as synthesized microbial crude protein/fermented organic matter in compliance with GfE [15]. Values are presented as means. \# Pooled standard deviation. 
In the same manner digestibility of $\mathrm{ADF}_{\mathrm{om}}$ (Table 9) did not differ between more and less efficient animals. However, digestibility of $\mathrm{aNDF}_{\mathrm{om}}$ (Table 9) tended to be higher in the less efficient group compared to the more efficient group $\left(p_{\mathrm{mCP} / \mathrm{fOM}}=0.086\right)$. Furthermore, digestibility of OM at the duodenum (Table 9) was significantly lower in more efficient animals $\left(p_{\mathrm{mCP} / \mathrm{fOM}}=0.001\right)$.

The tdDM differed significantly between $C_{60}$ and $C_{35}$ groups $\left(p_{c}=0.030\right.$, Figure 5$)$ as well as between more and less efficient groups $\left(p_{\mathrm{mCP} / \mathrm{fOM}}=0.026\right.$, Figure 5$)$. In the first case, higher $\mathrm{C}$ led to higher digestibility. In the second case, less efficient cows exhibited higher values.

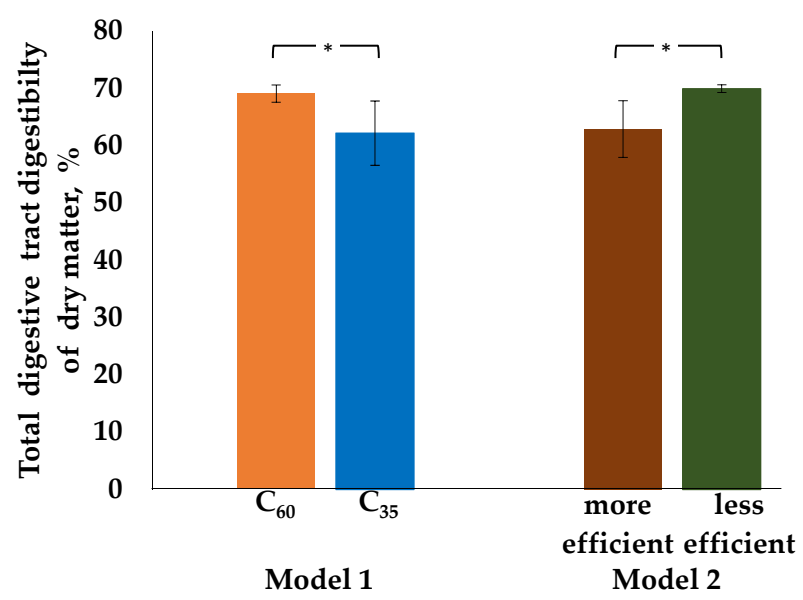

Figure 5. Total digestive tract digestibility of dry matter for the week of duodenal chyme sampling (on average week 13 postpartum \pm 16 days). After calving cows were assigned to a group with $60 \%$ concentrate feed proportion (increasing from 35 to $60 \%$ during the first three weeks after parturition, $C_{60}$, orange, $\left.n=5\right)$ and a group with $35 \%$ concentrate feed proportion $\left(C_{35}\right.$, blue, $\left.n=4\right)$ in the ration (model 1). For the week of duodenal chyme sampling, cows were additionally grouped into a more $(206 \pm 17 \mathrm{~g} / \mathrm{kg}$, red, $\mathrm{n}=5)$ and a less efficient $(122 \pm 17 \mathrm{~g} / \mathrm{kg}$, green, $\mathrm{n}=4)$ group in compliance with the average microbial efficiency of $156 \mathrm{~g} / \mathrm{kg}$, defined as synthesized microbial crude protein/fermented organic matter according to GfE [15] (model 2). *Indicating significant group differences. $\mathrm{C}_{60}$ vs. $\mathrm{C}_{35}$ : $p$-value $=0.030$, more efficient vs less efficient: $p$-value $=0.026$.

The same is true for the total digestive tract digestibility quotient of $\mathrm{OM}\left(p_{\mathrm{c}}=0.003, p_{\mathrm{mCP} / \mathrm{fOM}}=\right.$ 0.027, Table 9). $C_{60}$ and $C_{35}$ animals did not differ in their total digestive tract digestibility quotient of aNDF $F_{\text {om }}$ and $\mathrm{ADF}_{\mathrm{om}}$ (Table 9). Furthermore, the less efficient group had a significantly higher total digestive tract digestibility quotients of $\mathrm{aNDF}_{\mathrm{om}}\left(p_{\mathrm{mCP} / \mathrm{fOM}}=0.036\right.$, Table 9$)$ and $\mathrm{ADF}_{\mathrm{om}}\left(p_{\mathrm{mCP} / \mathrm{fOM}}=\right.$ 0.017, Table 9) compared to the more efficient group.

\subsection{Correlations and Regression Analysis}

However, as we found a tendency of $\beta 0$ being influenced by different concentrate feed proportions of the ration, we attempted to examine this relation more closely. Therefore, we correlated the $\beta 0$ values with the actual concentrate intake of period 1 and then detected a significant relation $\left(\mathrm{r}^{2}=0.311\right.$, $p<0.05$, Figure 4B). Animals which consumed more concentrate feed exhibited smaller $\beta 0$ values and therefore had a more fluctuating ruminal $\mathrm{pH}$ over the day.

Ruminal pH, Duodenal Nutrient Flows, and Microbial Crude Protein

We calculated further correlations and performed regression analysis with measured and calculated variables of the duodenal chyme collection to further assess the assumed $\mathrm{pH}$ influence on microbial efficiency, which was not verifiable in the intergroup comparison.

Hereby, we could detect a positive relation between $\beta 1$ and DMF $\left(\mathrm{r}^{2}=0.598, p<0.01\right.$, Figure $\left.6 \mathrm{~A}\right)$, as well as between $\beta 1$ and OMF $\left(\mathrm{r}^{2}=0.594, p<0.01\right.$, Figure $\left.6 \mathrm{~B}\right)$ for the week of duodenal chyme 
collection. Furthermore, increasing DMF was associated with a higher flow of microbial crude protein $\left(r^{2}=0.646, p<0.05\right.$, Figure 6C). The same is true for OMF $\left(r^{2}=0.536, p=0.061\right.$, Figure 6D).

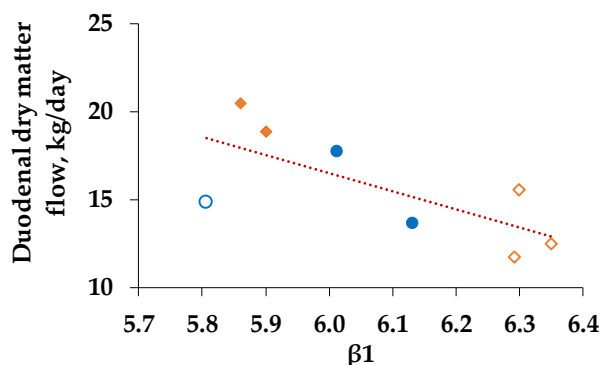

(A)

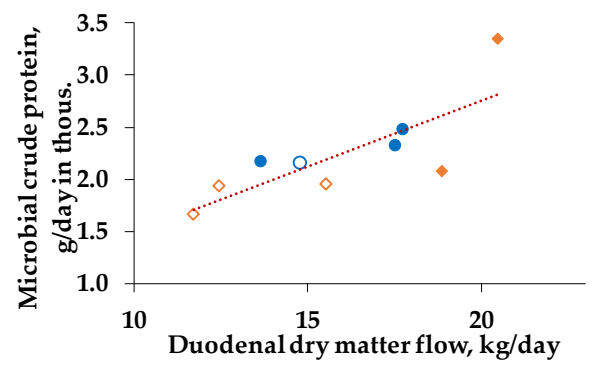

(C)

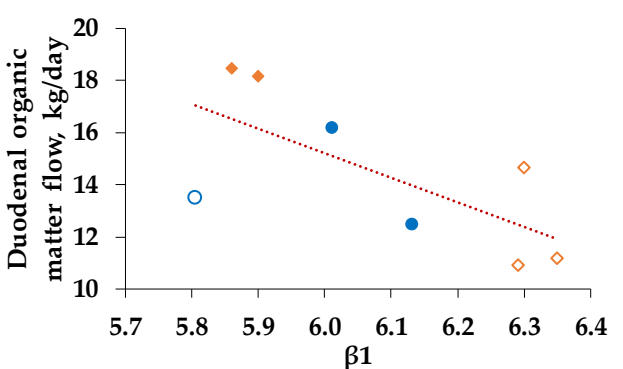

(B)

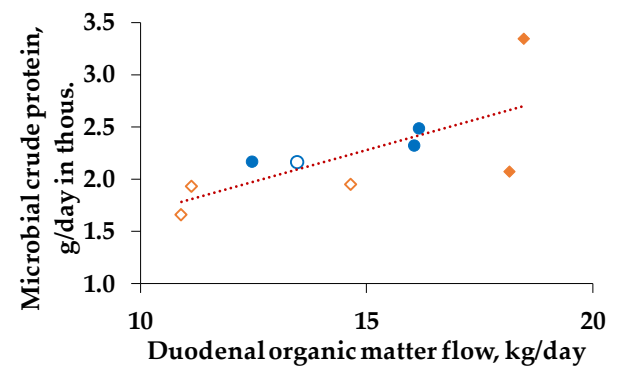

(D)

Figure 6. Regression of $\beta 1$ (describing the inflection point of the curve and representing the average $\mathrm{pH}$ of the $24 \mathrm{~h}$ period) on duodenal dry matter flow (DMF, $\mathbf{A}, \mathrm{y}=-10.25 \mathrm{x}+77.97, \mathrm{r}^{2}=0.598, p<0.05$ ) and of $\beta 1$ on duodenal organic matter flow (OMF, $\left.\mathbf{B}, \mathrm{y}=-9.42 \mathrm{x}+71.74, \mathrm{r}^{2}=0.594, p<0.05\right)$, as well as of DMF microbial crude protein $\left(C, y=0.13 x+0.23, \mathrm{r}^{2}=0.646, p<0.05\right)$ and of OMF on microbial crude protein $\left(\mathbf{D}, \mathrm{y}=0.12 \mathrm{x}+0.47, \mathrm{r}^{2}=0.536, p=0.061\right)$ for the duodenal fistulated cows $(\mathrm{n}=9)$ for the week of duodenal chyme sampling (in average week 13 postpartum \pm 16 days). After calving cows were assigned to a group with $60 \%$ concentrate feed proportion (increasing from $35-60 \%$ during the first three weeks after parturition, $\mathrm{C}_{60}$, orange, $\mathrm{n}=5$ ) and a group with $35 \%$ concentrate feed proportion $\left(\mathrm{C}_{35}\right.$, blue, $\left.\mathrm{n}=4\right)$ in the ration. For the week of duodenal chyme sampling cows were additionally grouped into a more $(206 \pm 17 \mathrm{~g} / \mathrm{kg}, \bullet / \vee, \mathrm{n}=5)$ and a less efficient $(122 \pm 17 \mathrm{~g} / \mathrm{kg}, \mathrm{O} / \diamond, \mathrm{n}=4)$ group in compliance with the average microbial efficiency of $156 \mathrm{~g} / \mathrm{kg}$, defined as synthesized microbial crude protein/fermented organic matter according to GfE [15]. Correlation of (A) and (B) was conducted with eight animals, due to a missing $\beta 1$ value for one more efficient cow of $C_{35}$.

\section{Discussion}

The aim of the present study was to examine the ruminal $\mathrm{pH}$ caused by differing concentrate feed proportions, thereby paying special attention to diurnal $\mathrm{pH}$-kinetics. The second objective of the study was to gain information on the interplay between ruminal $\mathrm{pH}$ parameters and microbial efficiency. For this, cows were additionally (retrospective) grouped according to their individual microbial efficiency. Therefore, the mean microbial efficiency of $156 \mathrm{~g} \mathrm{mCP} / \mathrm{kg}$ fOM according to GfE [15] was used as threshold for allocating the cows to more $(>156 \mathrm{~g} / \mathrm{kg}$ ) or less $(<156 \mathrm{~g} / \mathrm{kg})$ efficient. Moreover, efficiency related parameters, such as nutrient flows and digestibilities were examined.

In the transition period, cows decrease dry matter intake (DMI) and net energy intake (NEI) during the last days prior to calving and increase it again gradually after parturition [39]. This finding is substantiated by the significantly stronger increase in NEI and starch intake of group $\mathrm{C}_{60}$ resulting both from the slightly enhanced $\mathrm{DMI}$ and the higher $\mathrm{NE}_{\mathrm{L}}$ - and starch content of the ration.

We had expected that the higher starch intake of this group would lower the ruminal $\mathrm{pH}$. A higher starch intake had been shown to increase the production of SCFA and thus decrease ruminal $\mathrm{pH}$ [5]. However, in the present study, we could not prove this inverse relation to $\mathrm{pH}$ parameters such as daily mean $\mathrm{pH}$, time per day with $\mathrm{pH}<5.8$ and $\beta 1$. Considering the SARA defining thresholds according to 
Zebeli et al. [9], described as a daily mean $\mathrm{pH}<6.16$ and the time per day with $\mathrm{pH}<5.8$ for more than $5.24 \mathrm{~h}$, we would have expected that cows fed higher $\mathrm{C}$ would decrease daily mean $\mathrm{pH}$ and increase time with $\mathrm{pH}<5.8$ more drastically than the $\mathrm{C}_{35}$ group. Surprisingly both groups achieved the critical ranges defined by Zebeli et al. [9]. However, high standard errors suggest a high individual variability, which probably prevented the detection of significant differences between groups. Other studies showed the opposite by observing a decrease in ruminal $\mathrm{pH}$ resulting from higher concentrate intake [40,41]. Possibly, difference of starch content between the rations in the present study must have been higher to provoke extremes. On the contrary, studies of Ueda et al. [5] and Beauchemin and Penner [1] confirm our results. Ruminal $\mathrm{pH}$ is not only influenced by ration composition, but also by the functionality of the epithelium and thus by absorption capacity to eliminate SCFA. Neutralization by buffers and passage to lower digestive tract are considered to be further factors influencing ruminal $\mathrm{pH}$ for compensating an increased SCFA production [7]. Beauchemin and Penner [1] assumed that the feed depression before calving already reduces the functionality of rumen epithelium and increases the susceptibility to SARA. Consequently, the rumen mucosa would be incapable of even dealing with lower $\mathrm{C}$ proportions, which might already result in critical $\mathrm{pH}$ values. Our study supports these findings.

Gao and Oba [42] suggest that cows can be either tolerant towards, or susceptible to SARA. Other studies confirm this hypothesis by assuming a high individual variability in ruminal $\mathrm{pH}$, due to individual variability in absorption capacity and adaptability of the epithelium as well as in feeding behavior [1,3,12]. Nevertheless, in the present study, cows with higher concentrate intake exhibited lower $\beta 0$ values, reflecting a more fluctuating ruminal $\mathrm{pH}$ independent from group classification, which supports the assumption that individuality might have covered treatment effects De Veth and Kolver [19] already highlighted that a comparison of daily mean $\mathrm{pH}$ presupposes stable $\mathrm{pH}$ conditions and that the daily $\mathrm{pH}$ variation is at least equally relevant. Other studies endorse the view that $\mathrm{pH}$ variations over the day are more relevant than the daily mean $\mathrm{pH}[19,43]$. Consequently, the relation between concentrate amount and $\mathrm{pH}$ parameters must not be neglected.

The susceptibility to SARA in early lactation is supposed to influence microbial efficiency by destabilizing the population of microorganisms [44]. Rapidly fermentable carbohydrates decrease the growth of cellulolytic bacteria and stimulate growth of lactobacilli [45]. These alterations might influence microbial efficiency to synthesize microbial protein related to fermented organic matter. Based on these assumptions, microbial efficiency might also be associated with $\mathrm{pH}$ variations. For a better understanding of these associations, we retrospectively grouped the cows according to their microbial efficiency irrespective of the initial diet-based grouping.

Different studies had already indicated a missing effect of $C$ on microbial efficiency $[5,18]$. Our results support these findings, as we could not detect any differences between the $C_{60}$ and the $C_{35}$ groups in $\mathrm{mCP}, \mathrm{fOM}$ and $\mathrm{mCP} / \mathrm{fOM}$, supporting the idea to re-group the cows according to their microbial efficiency, to gain more information.

We have hypothesized a direct relation between $\mathrm{pH}$ parameters and microbial efficiency. A low $\mathrm{pH}$ is considered to inhibit fiber digestion and thus decrease microbial efficiency in ruminants [13,14]. However, our results could not identify differences in $\mathrm{pH}$ parameters, neither between the more and less efficient groups nor between the $\mathrm{C}_{60}$ and $\mathrm{C}_{35}$ groups. The time with an unfavorable $\mathrm{pH}$ might have been too short to affect the cellulolytic bacteria [46]. Other studies have neither been successful to reduce celullose digestion by decreasing $\mathrm{pH}$ in ruminants or to find a direct relation between $\mathrm{pH}$ and microbial efficiency $[18,47,48]$. Oetzel [8] supports our findings and suggests that microbial response on a low $\mathrm{pH}$ or even SARA is slow and that multiple acidotic impacts are necessary to inhibit microbial activity. Additionally, concentration of cellulolytic bacteria is considered to be higher than necessary and thus this population remains as long as $\mathrm{pH}$ is not unfavorable for too long [49]. Nevertheless, in the present trial, negative relationships between $\beta 1$ and DMF, as well as OMF were observed. Both parameters decreased with increasing $\beta 1$ values. In turn, DMF and OMF were positively associated with microbial efficiency, possibly due to an accompanied decrease of predation by protozoa [50]. 
Oba and Allen [18] already indicated that a higher passage rate could increase microbial efficiency. A higher passage rate limits the microbial lysis as well as the use of energy for non-growth processes [18,51]. Rode et al. [52] demonstrated a higher passage rate with increasing concentrate proportions. Our study could not support these findings, neither for DMF nor for OMF. However, independent from $C$, more efficient cows showed higher DMF and OMF. These higher flows also explain the lower tdDM digestibility for more efficient cows in the present study [22]. Another possible explanation for lower digestibilities in the more efficient group might be that energy and substrate could not be used efficiently as digestibility increased, due to a fermentation rate that exceeded the microbial growth rate [18]. Sutton et al. [4] and Faichney et al. [53] already explained the missing relations in digestibility quotients at the duodenum and indicated that digestion in the colon partially compensates ruminal digestion in sheep. Conversely, missing differences in nutrient flows between $\mathrm{C}_{60}$ and $\mathrm{C}_{35}$ groups were accompanied by missing effects in digestibility. Only digestibility of OM analyzed at the duodenum was positively influenced by $C$, which is in line with the study of Yang et al. [12] and supports the idea of compensation in the lower digestive tract. The missing $C$ effects in nutrient flows and digestibility in the present study might be due to an undersized difference of starch between the experimental rations.

Unexpectedly, the more efficient group exposed lower fOM values, in agreement with the study of Oba and Allen [18]. Energy from fOM is considered to be limiting factor for microbial efficiency [18]. That indicates that factors other than energy limited microbial efficiency additionally [17]. According to Clark et al. [17] these factors include synchronization of degradation of feed to permanently provide nutrients for microorganisms, content of nutrients and rumen conditions. Thus, a high individual variation for microbial efficiency can be assumed [17]. The second main limiting parameter for microbial crude protein synthesis is ammonia-N. In the present study, ammonia-N did neither differ between the $C_{60}$ and $C_{35}$ group nor between the more and less efficient group. Oba and Allen [18] could neither observe a direct relation to microbial efficiency. One appropriate explanation might be that a certain level of ammonia saturation was achieved in the present study. It was demonstrated that microbial crude protein synthesis exceeds the maximum with an amount of $5 \mathrm{mg} / \mathrm{dL}$ and does not increase further with increasing ammonia concentration [54]. For the present study, it may seem obvious that DMF and OMF mainly influenced microbial efficiency by decreasing predation by protozoa and energy spilling.

\section{Conclusions}

Higher amounts of concentrate did not affect daily mean $\mathrm{pH}$ or time with $\mathrm{pH}<5.8$. It may be assumed that individual differences among cows in ruminal $\mathrm{pH}$ impeded detection of significant group differences, due to high standard errors. However, we could prove a positive relationship between concentrate intake and $\beta 0$ values, reflecting larger $\mathrm{pH}$ fluctuations. It seems that the ability to smoothly adapt to the rapid drop in $\mathrm{pH}$ decreases with increasing concentrate feed intake, whereby individual differences to cope with this challenge become more obvious.

Comparing the cows grouped by microbial efficiency did not reveal differences in $\mathrm{pH}$ parameters. However, a relation between daily $\mathrm{pH}$ fluctuation and DMF as well as OMF was found. DMF and OMF in turn, were positively associated with microbial protein synthesis. Consequently, microbial efficiency was at least indirectly influenced by daily $\mathrm{pH}$ variation.

Further research is necessary to complete and improve the understanding of the ruminal processes. Important influencing factors, such as feeding behavior, comprising meal sizes and number of meals per day, rumen functionality, including absorption capacity of the rumen epithelium, as well as saliva production and its buffering capacity and furthermore the microbiome itself were not assessed in the present study, but should also be considered.

Author Contributions: The experiment's conceptualization was initiated by J.H. (Jürgen Hummel), S.D., U.M., D.v.S., K.B.; Methodology and validation of data was done by K.B., M.J., R.S., J.H. (Julia Hartwiger)., D.v.S.; Formal analysis was performed by K.B., M.J.; Investigation was done by L.H., D.v.S., K.B.; Resources were looked up by K.B., M.J.; Curation and preparation, visualization of data was done by D.v.S., M.J., K.B.; Writing original draft 
preparation was performed by K.B.; Supervision and writing of the review was done by R.S., J.H. (Julia Hartwiger), D.v.S., L.H., U.M., S.D., H.W., J.H. (Jürgen Hummel), A.Z.; Editing was done by K.B.; Project was administrated by J.H. (Jürgen Hummel), U.M., S.D. All authors have read and agreed to the published version of the manuscript.

Funding: The project is part of indiKuh and supported by funds of the Federal Ministry of Food and Agriculture (BMEL) based on a decision of the Parliament of the Federal Republic of Germany via the Federal Office for Agriculture and Food (BLE) under the innovation support programme [grant number FKZ 2817905915].

Acknowledgments: The authors thank the co-workers of the Institute of Animal Nutrition and of the experimental station of the Institute of Animal Nutrition, Friedrich-Loeffler-Institut (FLI) in Brunswick for their support in taking care of the animals, sample and data collection as well as analyses.

Conflicts of Interest: The authors declare no conflict of interest.

\section{Appendix A}

Table A1. Effects of concentrate feed proportion in the diet (C) and period on dry matter intake (DMI), net energy intake (NEI), milk yield, energy corrected milk (ECM) and milk components during period 1 (weeks 1-2 postpartum), period 2 (weeks 3-4 postpartum), period 3 (weeks 5-6 postpartum), period 4 (weeks 7-8 postpartum) and period 5 (weeks 9-10 postpartum) in the treatment groups.

\begin{tabular}{|c|c|c|c|c|c|c|}
\hline \multirow{2}{*}{ Item } & \multicolumn{2}{|c|}{ Grouping $\S$} & \multirow{2}{*}{ SEM ${ }^{\#}$} & \multicolumn{3}{|c|}{$p$-Value } \\
\hline & $\begin{array}{c}C_{60} \\
n=6\end{array}$ & $\begin{array}{c}C_{35} \\
n=7\end{array}$ & & $\mathrm{C}$ & Period & $\mathrm{C} \times$ Period \\
\hline \multicolumn{7}{|c|}{ DMI, kg/day } \\
\hline Period 1 & 14.9 & 15.9 & 1.2 & 0.298 & $<0.001$ & 0.103 \\
\hline Period 2 & 20.3 & 19.4 & & & & \\
\hline Period 3 & 23.3 & 21.0 & & & & \\
\hline Period 4 & 24.2 & 21.6 & & & & \\
\hline Period 5 & 24.5 & 22.7 & & & & \\
\hline \multicolumn{7}{|c|}{ NEI, MJ NE $\mathrm{N}_{\mathrm{L}} /$ day } \\
\hline Period 1 & $106^{c}$ & $113^{b}$ & 8 & 0.133 & $<0.001$ & 0.016 \\
\hline Period 2 & $146_{b}$ & $135^{\mathrm{a}}$ & & & & \\
\hline Period 3 & $169^{a}$ & $146^{\mathrm{a}}$ & & & & \\
\hline Period 4 & $176^{\mathrm{a}}$ & $150^{a}$ & & & & \\
\hline Period 5 & $178^{a}$ & $158^{\mathrm{a}}$ & & & & \\
\hline \multicolumn{7}{|c|}{ Starch intake, kg/day } \\
\hline Period 1 & $4.6^{\mathrm{a}}$ & $4.5^{\mathrm{a}}$ & 0.4 & 0.004 & $<0.001$ & $<0.001$ \\
\hline Period 2 & $6.8^{\mathrm{b}}$ & $5.7^{\mathrm{b}}$ & & & & \\
\hline Period 3 & $8.3^{\mathrm{Ac}}$ & $6.1^{\mathrm{Bc}}$ & & & & \\
\hline Period 4 & 8.9 Ad & $6.2^{\mathrm{Bd}}$ & & & & \\
\hline Period 5 & $8.8^{\mathrm{Ae}}$ & $6.6^{\mathrm{Be}}$ & & & & \\
\hline \multicolumn{7}{|c|}{ Milk yield, kg/day } \\
\hline Period 1 & $23.3^{e}$ & $29.0^{\mathrm{b}}$ & 1.9 & 0.365 & $<0.001$ & $<0.001$ \\
\hline Period 2 & $32.8^{\mathrm{d}}$ & $36.9^{a}$ & & & & \\
\hline Period 3 & $36.8^{\mathrm{cd}}$ & $40.0^{\mathrm{a}}$ & & & & \\
\hline Period 4 & $40.8^{b}$ & $40.0^{\mathrm{a}}$ & & & & \\
\hline Period 5 & $41.0^{\mathrm{a}}$ & $40.2^{\mathrm{a}}$ & & & & \\
\hline \multicolumn{7}{|c|}{ Milk fat content, \% } \\
\hline Period 1 & $4.88^{\mathrm{a}}$ & $4.82^{\mathrm{a}}$ & 0.37 & 0.233 & $<0.001$ & $<0.001$ \\
\hline Period 2 & $3.93^{b}$ & $4.35^{\mathrm{ab}}$ & & & & \\
\hline Period 3 & $3.32 \mathrm{bc}$ & $4.07^{\mathrm{b}}$ & & & & \\
\hline Period 4 & $2.78^{c}$ & $3.82^{b}$ & & & & \\
\hline Period 5 & $2.81^{\mathrm{c}}$ & $3.79^{b}$ & & & & \\
\hline \multicolumn{7}{|c|}{ Milk fat yield, kg/day } \\
\hline Period 1 & $1.19^{\mathrm{c}}$ & $1.28^{\mathrm{c}}$ & 0.12 & 0.148 & 0.372 & 0.049 \\
\hline Period 2 & $1.30 \mathrm{bc}$ & $1.35 \mathrm{bc}$ & & & & \\
\hline Period 3 & $1.22^{a b}$ & $1.51 \mathrm{ab}$ & & & & \\
\hline Period 4 & $1.14^{\mathrm{a}}$ & $1.53^{\mathrm{a}}$ & & & & \\
\hline Period 5 & $1.17^{\mathrm{a}}$ & $1.50^{\mathrm{a}}$ & & & & \\
\hline
\end{tabular}


Table A1. Cont.

\begin{tabular}{|c|c|c|c|c|c|c|}
\hline \multirow{2}{*}{ Item } & \multicolumn{2}{|c|}{ Grouping $\S$} & \multirow{2}{*}{ SEM ${ }^{\#}$} & \multicolumn{3}{|c|}{$p$-Value } \\
\hline & $\begin{array}{c}\mathrm{C}_{60} \\
\mathrm{n}=6\end{array}$ & $\begin{array}{c}\mathrm{C}_{35} \\
\mathrm{n}=7\end{array}$ & & $\mathrm{C}$ & Period & $\mathrm{C} \times$ Period \\
\hline \multicolumn{7}{|c|}{$\begin{array}{l}\text { Milk protein } \\
\text { content, } \%\end{array}$} \\
\hline Period 1 & 3.90 & 3.52 & 0.17 & 0.297 & $<0.001$ & 0.363 \\
\hline Period 2 & 3.34 & 2.96 & & & & \\
\hline Period 3 & 3.26 & 3.04 & & & & \\
\hline Period 4 & 3.23 & 3.16 & & & & \\
\hline Period 5 & 3.29 & 3.18 & & & & \\
\hline \multicolumn{7}{|c|}{$\begin{array}{l}\text { Milk protein yield, } \\
\text { kg/day }\end{array}$} \\
\hline Period 1 & 0.94 & 1.04 & 0.08 & 0.944 & $<0.001$ & 0.162 \\
\hline Period 2 & 1.11 & 1.09 & & & & \\
\hline Period 3 & 1.20 & 1.22 & & & & \\
\hline Period 4 & 1.33 & 1.27 & & & & \\
\hline Period 5 & 1.36 & 1.27 & & & & \\
\hline \multicolumn{7}{|c|}{$\begin{array}{l}\text { Milk lactose } \\
\text { content, } \%\end{array}$} \\
\hline Period 1 & 4.49 & 4.26 & 0.21 & 0.560 & 0.002 & 0.312 \\
\hline Period 2 & 4.74 & 4.31 & & & & \\
\hline Period 3 & 4.76 & 4.61 & & & & \\
\hline Period 4 & 4.79 & 4.80 & & & & \\
\hline Period 5 & 4.80 & 4.85 & & & & \\
\hline \multicolumn{7}{|c|}{$\begin{array}{l}\text { Milk lactose yield, } \\
\text { kg/day }\end{array}$} \\
\hline Period 1 & $1.10^{\mathrm{c}}$ & $1.23^{b}$ & 0.17 & 0.762 & $<0.001$ & $<0.001$ \\
\hline Period 2 & $1.57^{\mathrm{b}}$ & $1.59^{\mathrm{a}}$ & & & & \\
\hline Period 3 & $1.75^{b}$ & $1.71^{\mathrm{a}}$ & & & & \\
\hline Period 4 & $1.97^{\mathrm{a}}$ & $1.72^{\mathrm{a}}$ & & & & \\
\hline Period 5 & $1.97^{\mathrm{a}}$ & $1.73^{a}$ & & & & \\
\hline \multicolumn{7}{|c|}{$\begin{array}{l}\text { Milk fat:protein } \\
\text { ratio }\end{array}$} \\
\hline Period 1 & $1.26^{\mathrm{a}}$ & $1.31^{\mathrm{a}}$ & 0.12 & 0.175 & $<0.001$ & 0.002 \\
\hline Period 2 & $1.18^{\mathrm{ab}}$ & $1.34^{\mathrm{a}}$ & & & & \\
\hline Period 3 & $1.03^{b c}$ & $1.29^{a}$ & & & & \\
\hline Period 4 & $0.86^{c}$ & $1.21^{\mathrm{a}}$ & & & & \\
\hline Period 5 & $0.86^{\mathrm{c}}$ & $1.19^{\mathrm{a}}$ & & & & \\
\hline \multicolumn{7}{|c|}{ ECM, kg/day } \\
\hline Period 1 & 27.69 & 34.61 & 2.17 & 0.093 & $<0.001$ & 0.210 \\
\hline Period 2 & 32.85 & 38.77 & & & & \\
\hline Period 3 & 33.62 & 39.80 & & & & \\
\hline Period 4 & 34.87 & 38.93 & & & & \\
\hline Period 5 & 35.36 & 38.64 & & & & \\
\hline
\end{tabular}

abcde least square means (LSMeans) with different superscripts differ within columns. ${ }^{\mathrm{AB}}$ LSMeans with different superscripts differ within row. ${ }^{\S}$ After calving cows were assigned to a group with $60 \%$ concentrate feed proportion (increasing from $35-60 \%$ during the first three weeks after parturition, $\mathbf{C}_{60}$ ) and a group with $35 \%$ concentrate feed proportion $\left(\mathrm{C}_{35}\right)$ in the ration. Values are presented as LSMeans. ${ }^{\text {P }}$ Pooled standard error of means. 
Table A2. Group allocation based on the individual microbial efficiency.

\begin{tabular}{ccc}
\hline Cow Number & Group Allocation & Individual Microbial Efficiency \\
\hline 1 & More efficient & 191.86 \\
2 & More efficient & 215.75 \\
3 & Less efficient & 114.65 \\
4 & More efficient & 198.03 \\
5 & More efficient & 193.02 \\
6 & Less efficient & 122.20 \\
7 & More efficient & 231.77 \\
8 & Less efficient & 145.98 \\
9 & Less efficient & 106.92 \\
\hline
\end{tabular}

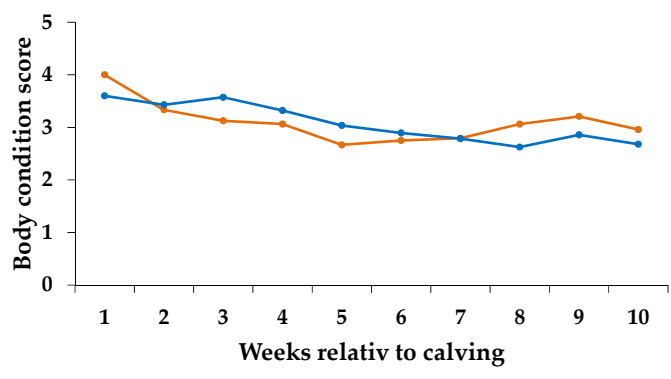

(A)

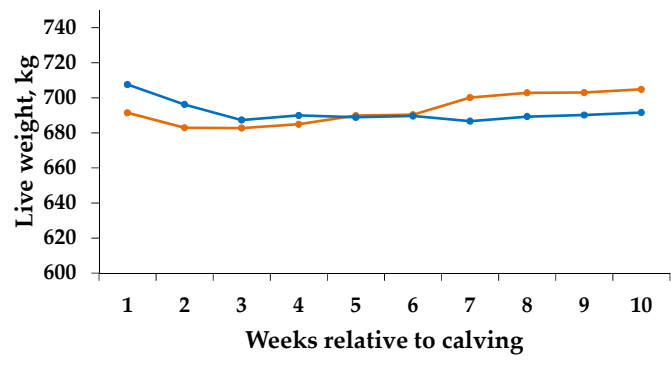

(B)

Figure A1. Progress of body condition score (A) and live weight (B) during the first 10 weeks postpartum. After calving cows were assigned to a group with $60 \%$ concentrate feed proportion (increasing from $35-60 \%$ during the first three weeks after parturition, $\mathrm{C}_{60}$, orange, $\mathrm{n}=5$ ) and a group with $35 \%$ concentrate feed proportion $\left(C_{35}\right.$, blue, $\left.n=4\right)$ in the ration.

Table A3. Effects of microbial efficiency (synthesized microbial crude protein/fermented organic matter) on dry matter intake (DMI), milk yield, energy corrected milk (ECM) and milk components during the week of duodenal chyme sampling.

\begin{tabular}{ccccc}
\hline \multirow{2}{*}{ Item $^{+}$} & \multicolumn{2}{c}{ Grouping $^{\S}$} & \multirow{2}{*}{ SD $^{\#}$} & \multirow{2}{*}{$\boldsymbol{p}$-Value } \\
\cline { 2 - 3 } & $\begin{array}{c}\text { More Efficient } \\
\mathbf{n = 5}\end{array}$ & $\begin{array}{c}\text { Less Efficient } \\
\mathbf{n = 4}\end{array}$ & & \\
\hline DMI, kg/day & 23.9 & 25.3 & 2.7 & 0.515 \\
Milk yield, kg/day & 41.2 & 40.3 & 4.7 & 0.783 \\
Milk fat content, \% & 3.32 & 3.16 & 0.51 & 0.731 \\
Milk fat yield, kg/day & 1.35 & 1.30 & 0.21 & 0.781 \\
Milk protein content, \% & 3.31 & 3.26 & 0.20 & 0.711 \\
Milk protein yield, kg/day & 1.36 & 1.35 & 0.18 & 0.923 \\
Milk lactose content, \% & 4.77 & 4.88 & 0.08 & 0.100 \\
Milk fat:protein ratio & 0.99 & 0.97 & 0.15 & 0.864 \\
ECM, kg/day & 37.4 & 37.1 & 4.4 & 0.919 \\
\hline
\end{tabular}

${ }^{+}$Intergroup comparison for the week of duodenal chyme sampling (on average week 13 postpartum \pm 16 days), for the more and the less efficient groups. ${ }^{\S}$ For the week of duodenal chyme sampling cows were grouped into a more $(206 \pm 17 \mathrm{~g} / \mathrm{kg}, \mathrm{n}=5)$ and a less efficient $(122 \pm 17 \mathrm{~g} / \mathrm{kg}, \mathrm{n}=4)$ group according to the mean microbial efficiency of 156 $\mathrm{g} / \mathrm{kg}$, defined as synthesized microbial crude protein/fermented organic matter in compliance with GfE [15]. Values are presented as means. "\# Pooled standard deviation. 


\section{References}

1. Beauchemin, K.; Penner, G. New developments in understanding ruminal acidosis in dairy cows. In Proceedings of the Tri-State Dairy Nutrition Conference, Grand Wayne Convention Center, Fort Wayne, IN, USA, 21-22 April 2009; pp. 1-12.

2. Veerkamp, R.; Beerda, B.; Van der Lende, T. Effects of genetic selection for milk yield on energy balance, levels of hormones, and metabolites in lactating cattle, and possible links to reduced fertility. Livest. Sci. 2003, 83, 257-275. [CrossRef]

3. Bannink, A.; Gerrits, W.; France, J.; Dijkstra, J. Variation in rumen fermentation and the rumen wall during the transition period in dairy cows. Anim. Feed. Sci. Technol. 2012, 172, 80-94. [CrossRef]

4. Sutton, J.D.; Knight, R.; McAllan, A.B.; Smith, R.H. Digestion and synthesis in the rumen of sheep given diets supplemented with free and protected oils. Br. J. Nutr. 1983, 49, 419-432. [CrossRef] [PubMed]

5. Ueda, K.; Ferlay, A.; Chabrot, J.; Loor, J.; Chilliard, Y.; Doreau, M. Effect of linseed oil supplementation on ruminal digestion in dairy cows fed diets with different forage: Concentrate ratios. J. Dairy Sci. 2003, 86, 3999-4007. [CrossRef]

6. Dirksen, G.; Liebich, H.; Brosi, G.; Hagemeister, H.; Mayer, E. Morphology of the rumen mucosa and fatty acid absorption in cattle-Important factors for health and production. Transbound. Emerg. Dis. 1984, 31, 414-430.

7. Allen, M.S. Relationship between fermentation acid production in the rumen and the requirement for physically effective fiber. J. Dairy Sci. 1997, 80, 1447-1462. [CrossRef]

8. Oetzel, G.R. Subacute ruminal acidosis in dairy herds: Physiology, pathophysiology, milk fat responses, and nutritional management. In Dairy Herd Problem Investigation Strategies: Lameness, Cow Comfort, and Ruminal Acidosis. 40th Annual Conference; American Association of Bovine Practitioners: Vancouver, BC, Canada, 17 September 2007; pp. 89-119.

9. Zebeli, Q.; Dijkstra, J.; Tafaj, M.; Steingass, H.; Ametaj, B.; Drochner, W. Modeling the adequacy of dietary fiber in dairy cows based on the responses of ruminal $\mathrm{pH}$ and milk fat production to composition of the diet. J. Dairy Sci. 2008, 91, 2046-2066. [CrossRef]

10. Nordlund, K.V.; Garrett, E.F.; Oetzel, G.R. Herd-based rumenocentesis-a clinical approach to the diagnosis of sub acute rumen acidosis. Transbound. Emerg. Dis 1995, 17, 48-56.

11. Schmitz, R.; Schnabel, K.; von Soosten, D.; Meyer, U.; Hüther, L.; Spiekers, H.; Rehage, J.; Dänicke, S. Changes of ruminal $\mathrm{pH}$, rumination activity and feeding behaviour during early lactation as affected by different energy and fibre concentrations of roughage in pluriparous dairy cows. Arch. Anim. Nutr. 2018, 72, 458-477. [CrossRef]

12. Yang, W.; Beauchemin, K.; Rode, L. Effects of grain processing, forage to concentrate ratio, and forage particle size on rumen $\mathrm{pH}$ and digestion by dairy cows. J. Dairy Sci. 2001, 84, 2203-2216. [CrossRef]

13. Ørskov, E.; Fraser, C. The effects of processing of barley-based supplements on rumen $\mathrm{pH}$, rate of digestion and voluntary intake of dried grass in sheep. Br. J. Nutr. 1975, 34, 493-500. [CrossRef] [PubMed]

14. Russell, J.B.; Wilson, D.B. Why are ruminal cellulolytic bacteria unable to digest cellulose at low pH? J. Dairy Sci. 1996, 79, 1503-1509. [CrossRef]

15. GfE. Gesellschaft für Ernährungsphysiologie. Empfehlungen zur Energie-und Nährstoffversorgung der Milchkühe und Aufzuchtrinder; DLG-Verlags-GmbH: Frankfurt am Main, Germany, 2001.

16. Strobel, H.J.; Russell, J.B. Effect of $\mathrm{pH}$ and energy spilling on bacterial protein synthesis by carbohydrate-limited cultures of mixed rumen bacteria. J. Dairy Sci. 1986, 69, 2941-2947. [CrossRef]

17. Clark, J.; Klusmeyer, T.; Cameron, M. Microbial protein synthesis and flows of nitrogen fractions to the duodenum of dairy cows. J. Dairy Sci. 1992, 75, 2304-2323. [CrossRef]

18. Oba, M.; Allen, M. Effects of diet fermentability on efficiency of microbial nitrogen production in lactating dairy cows. J. Dairy Sci. 2003, 86, 195-207. [CrossRef]

19. De Veth, M.; Kolver, E. Diurnal variation in $\mathrm{pH}$ reduces digestion and synthesis of microbial protein when pasture is fermented in continuous culture. J. Dairy Sci. 2001, 84, 2066-2072. [CrossRef]

20. Russell, J.B.; O'Connor, J.; Fox, D.; Van Soest, P.; Sniffen, C. A net carbohydrate and protein system for evaluating cattle diets: I. Ruminal fermentation. J. Anim. Sci. 1992, 70, 3551-3561. [CrossRef]

21. Thompson, F.; Lamming, G. The flow of digesta, dry matter and starch to the duodenum in sheep given rations containing straw of varying particle size. Br. J. Nutr. 1972, 28, 391-403. [CrossRef] 
22. Firkins, J.; Yu, Z.; Morrison, M. Ruminal nitrogen metabolism: Perspectives for integration of microbiology and nutrition for dairy. J. Dairy Sci. 2007, 90. [CrossRef]

23. Wells, J.E.; Russell, J.B. Why do many ruminal bacteria die and lyse so quickly? J. Dairy Sci. 1996, 79, 1487-1495. [CrossRef]

24. Bach, A.; Calsamiglia, S.; Stern, M. Nitrogen metabolism in the rumen. J. Dairy Sci. 2005, 88. [CrossRef]

25. Hoover, W.H. Chemical factors involved in ruminal fiber digestion. J. Dairy Sci. 1986, 69, $2755-2766$. [CrossRef]

26. Schäfers, S.; Meyer, U.; von Soosten, D.; Krey, B.; Hüther, L.; Tröscher, A.; Pelletier, W.; Kienberger, H.; Rychlik, M.; Dänicke, S. Influence of vitamin E on organic matter fermentation, ruminal protein and fatty acid metabolism, protozoa concentrations and transfer of fatty acids. J. Anim. Physiol. Anim. Nutr. 2018, 102, 1111-1119. [CrossRef]

27. Geissler, C.; Hoffmann, M.; Hiokel, B. Ein Beitrag zur gaschromatographischen Bestimmung flüchtiger Fettsäuren. Arch. Anim. Nutr. 1976, 26, 123-129. [CrossRef]

28. Anonymous. DIN 38406-E5-2. In Deutsche Einheitsverfahren zur Wasser-, Abwasser-und Schlammuntersuchung. 40. Lieferung; Wiley-VCH: Weinheim, Germany, 1998.

29. VDLUFA. Verband Deutscher Landwirtschaftlicher Untersuchungs- und Forschungsanstalten. Handbuch der landwirtschaftlichen Versuchs- und Untersuchungsmethodik (VDLUFA-Methodenbuch), Bd. III: Die chemische Untersuchung von Futtermitteln; VDLUFA-Verlag: Darmstadt, Germany, 2006.

30. Williams, C.; David, D.J.; Iismaa, O. The determination of chromic oxide in faeces samples by atomic absorption spectrophotometry. J. Agric. Sci. 1962, 59, 381-385. [CrossRef]

31. Lebzien, P.; Paul, C. Use of near-infrared reflectance spectroscopy for the estimation of the microbial portion of non-ammonia-nitrogen in the duodenum of dairy cows. Anim. Feed Sci. Technol. 1997, 68, 225-233. [CrossRef]

32. Pappritz, J.; Lebzien, P.; Meyer, U.; Jahreis, G.; Kramer, R.; Flachowsky, G.; Dänicke, S. Duodenal availability of conjugated linoleic acids after supplementation to dairy cow diets. Eur. J. Lipid Sci. Technol. 2011, 113, 1443-1455. [CrossRef]

33. Simon, O. Verdauung und Resorption. In Ernährung landwirtschaftlicher Nutztiere: Ernährungsphysiologie, Futtermittelkunde, Fütterung; Jeroch, H., Drochner, W., Simon, O., Eds.; Eugen Ulmer KG: Stuttgard, Germany, 2008; Volume 130, pp. 109-132.

34. McGinn, S.; Beauchemin, K.; Coates, T.; Colombatto, D. Methane emissions from beef cattle: Effects of monensin, sunflower oil, enzymes, yeast, and fumaric acid. J. Anim. Sci. 2004, 82, 3346-3356. [CrossRef]

35. Littell, R.; Henry, P.; Ammerman, C. Statistical analysis of repeated measures data using SAS procedures. J. Anim. Sci. 1998, 76, 1216-1231. [CrossRef]

36. AlZahal, O.; Kebreab, E.; France, J.; McBride, B. A mathematical approach to predicting biological values from ruminal pH measurements. J. Dairy Sci. 2007, 90, 3777-3785. [CrossRef]

37. Colman, E.; Tas, B.; Waegeman, W.; De Baets, B.; Fievez, V. The logistic curve as a tool to describe the daily ruminal $\mathrm{pH}$ pattern and its link with milk fatty acids. J. Dairy Sci. 2012, 95, 5845-5865. [CrossRef] [PubMed]

38. Schären, M.; Seyfang, G.; Steingass, H.; Dieho, K.; Dijkstra, J.; Hüther, L.; Frahm, J.; Beineke, A.; von Soosten, D.; Meyer, U.; et al. The effects of a ration change from a total mixed ration to pasture on rumen fermentation, volatile fatty acid absorption characteristics, and morphology of dairy cows. J. Dairy Sci. 2016, 99, 3549-3565. [CrossRef] [PubMed]

39. Dänicke, S.; Meyer, U.; Kersten, S.; Frahm, J. Animal models to study the impact of nutrition on the immune system of the transition cow. Res. Vet. Sci. 2018, 116, 15-27. [CrossRef] [PubMed]

40. Krause, K.M.; Combs, D.K.; Beauchemin, K.A. Effects of forage particle size and grain fermentability in midlactation cows. II. Ruminal pH and chewing activity. J. Dairy Sci. 2002, 85, 1947-1957. [CrossRef]

41. Agle, M.; Hristov, A.N.; Zaman, S.; Schneider, C.; Ndegwa, P.M.; Vaddella, V.K. Effect of dietary concentrate on rumen fermentation, digestibility, and nitrogen losses in dairy cows. J. Dairy Sci. 2010, 93, 4211-4222. [CrossRef]

42. Gao, X.; Oba, M. Relationship of severity of subacute ruminal acidosis to rumen fermentation, chewing activities, sorting behavior, and milk production in lactating dairy cows fed a high-grain diet. J. Dairy Sci. 2014, 97, 3006-3016. [CrossRef] 
43. Rustomo, B.; AlZahal, O.; Cant, J.; Fan, M.; Duffield, T.; Odongo, N.; McBride, B. Acidogenic value of feeds II. Effects of rumen acid load from feeds on dry matter intake, ruminal $\mathrm{pH}$, fibre degradability and milk production in the lactating dairy cow. Can. J. Anim. Sci. 2006, 86, 119-127.

44. Nagaraja, T.; Titgemeyer, E. Ruminal acidosis in beef cattle: The current microbiological and nutritional outlook. J. Dairy Sci. 2007, 90. [CrossRef]

45. Slyter, L.; Oltjen, R.; Kern, D.; Blank, F. Influence of type and level of grain and diethylstilbestrol on the rumen microbial populations of steers fed all-concentrate diets. J. Anim. Sci. 1970, 31, 996-1002. [CrossRef]

46. Mould, F.; Ørskov, E. Manipulation of rumen fluid $\mathrm{pH}$ and its influence on cellulolysis in sacco, dry matter degradation and the rumen microflora of sheep offered either hay or concentrate. Anim. Feed Sci. Technol. 1983, 10, 1-14. [CrossRef]

47. Hiltner, P.; Dehority, B. Effect of soluble carbohydrates on digestion of cellulose by pure cultures of rumen bacteria. Appl. Environ. Microbiol. 1983, 46, 642-648. [CrossRef]

48. De Veth, M.; Kolver, E. Digestion of ryegrass pasture in response to change in $\mathrm{pH}$ in continuous culture. J. Dairy Sci. 2001, 84, 1449-1457. [CrossRef]

49. Weimer, P.J. Manipulating ruminal fermentation: A microbial ecological perspective. J. Anim. Sci. 1998, 76, 3114-3122. [CrossRef]

50. Wallace, R.J.; McPherson, C.A. Factors affecting the rate of breakdown of bacterial protein in rumen fluid. Br. J. Nutr. 1987, 58, 313-323. [CrossRef]

51. Dijkstra, J.; Kebreab, E.; Bannink, A.; France, J.; Lopez, S. Application of the gas production technique to feed evaluation systems for ruminants. Anim. Feed Sci. Technol. 2005, 123, 561-578. [CrossRef]

52. Rode, L.; Weakley, D.; Satter, L. Effect of forage amount and particle size in diets of lactating dairy cows on site of digestion and microbial protein synthesis. Can. J. Anim. Sci. 1985, 65, 101-111. [CrossRef]

53. Faichney, G.; Gordon, G.; Welch, R.; Rintoul, A. Effect of dietary free lipid on anaerobic fungi and digestion in the rumen of sheep. Aust. J. Agr. Res. 2002, 53, 519-527. [CrossRef]

54. Satter, L.; Slyter, L. Effect of ammonia concentration on rumen microbial protein production in vitro. $B r$. J. Nutr. 1974, 32, 199-208. [CrossRef] 